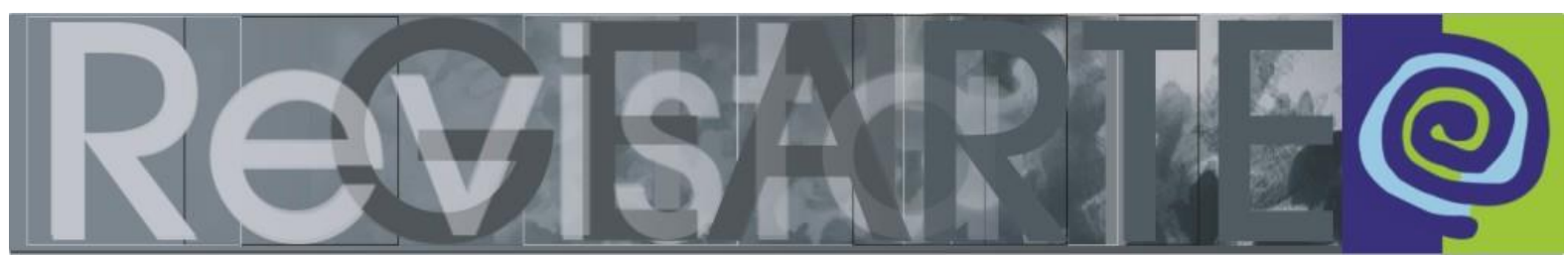

ISSN 2357-9854 | e-ISSN 2596-3198 (online)

\title{
Ensino/Aprendizagem das Artes Visuais na América Latina: colonialidade cultural e emocional aliada a questões LGBT
}

\author{
Fábio José Rodrigues da Costa \\ (Universidade Regional do Cariri - URCA, Crato/Ceará, Brasil)
}

\begin{abstract}
RESUMO - Ensino/Aprendizagem das Artes Visuais na América Latina: colonialidade cultural e emocional aliada a questões LGBT - Este artigo se situa em um lugar de fala, de existência, de resistência e (re)existência de seu autor como membro da população LGBT do Brasil. Situado nesse lugar de identidades e pertencimentos indaga sobre as relações entre o ensino/aprendizagem das artes visuais na América Latina a partir das pesquisas em desenvolvimento no Grupo de Pesquisa Ensino da Arte em Contextos Contemporâneos - GPEACC/CNPq do Centro de Artes da Universidade Regional do Cariri - URCA. Nosso objetivo tem sido o de decolonializar o ensino de Arte no contexto da escola de Educação Básica, especificamente, o ensino das artes visuais. Em um primeiro momento, entendíamos que a decolonialidade ocorreria por meio da inserção de artistas ativistas e artivistas LGBT na seleção das/os professoras/es. No entanto, a partir dos estudos sobre a decolonialidade ou a opção decolonial requer pensar também o conhecimento das professoras e professores, e pensar sobre o conhecimento acumulado por estas e estes profissionais da educação, aponta para um exercício de aprender a desaprender. A partir do "aprender a desaprender", como estratégia para que nós, latinoamericanas e latino-americanos, possamos aprender a desaprender sobre nós mesmos como condição para a construção de um projeto emancipatório.
\end{abstract}

PALAVRAS-CHAVE

LGBT. Aprender. Desaprender. Decolonial. Artes Visuais.

RESUMEN - Enseñanza / Aprendizaje de Artes Visuales en América Latina: colonialidad cultural y emocional junto con temas LGBT - Este artículo está situado en un lugar de expresión, existencia, resistencia y (re) existencia de su autor como miembro de la población LGBT brasileña. Ubicado en este lugar de identidades y pertenencias, investiga la relación entre la enseñanza / aprendizaje de las artes visuales en América Latina a partir de la investigación en el Grupo de Investigación Enseñanza del Arte en Contextos Contemporáneos - GPEACC / CNPq del Centro de Artes de la Universidade Regional de Cariri - URCA. Nuestro objetivo ha sido decolonializar la enseñanza del arte en el contexto de la escuela de educación básica, específicamente, la enseñanza de las artes visuales. Al principio, comprendimos que la decolonialidad se produciría a través de la inserción de artistas activistas y artivistas LGBT en la selección de los maestros. Sin embargo, a partir de los estudios sobre la decolonialidad o la opción decolonial, también es necesario pensar en el conocimiento de maestras y maestros, y pensar en el conocimiento acumulado por estas y estos profesionales de la educación, que apunta a un ejercicio de aprendizaje para desaprender. Desde "aprender a desaprender", como estrategia para nosotros, las / los latinoamericanas y latinoamericanos, para aprender a desaprender de nosotros mismos como una condición para construir un proyecto emancipador.

PALABRAS CLAVE

LGBT. Aprender. Desaprender. Decolonial. Artes Visuales. 


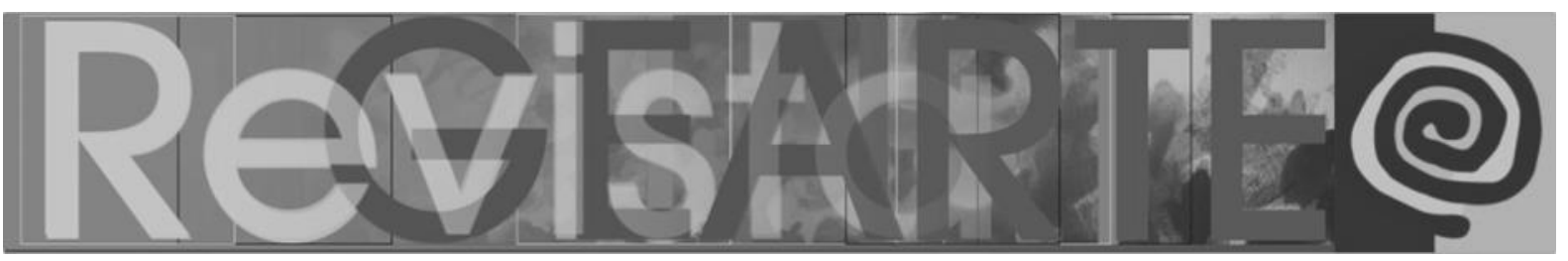

"Fear must be like something seasonig for freedom" (O medo deve ser como um tempero para a liberdade) Alair Gomes (Diário entre 1985 a 1989)1.

\section{Introdução}

Ao receber o convite para colaborar com o debate como participante da mesa "O Colonialismo Cultural e emocional aliada a questões de gênero, raça, classe social e códigos hegemônicos de cultura", uma das temáticas do Congresso Internacional "Ensino/Aprendizagem das Artes na América Latina: Colonialismo e Questões de Gênero", me vi envolto em uma problemática, pois considerei impossível tratar de todas as especificidades e complexidades que o tema sugere. Considerei viável e até mesmo necessário fazer um recorte no recorte proposto, e deste modo me situar em um lugar de fala, de existência, de resistência e (re)existência como membro da população LGBT do Brasil. Situando-me nesse lugar de identidades e pertencimentos passei a indagar sobre as relações entre o ensino/aprendizagem das artes visuais na América Latina a partir das pesquisas que venho desenvolvendo com minhas/meus estudantes no Grupo de Pesquisa Ensino da Arte em Contextos Contemporâneos GPEACC/CNPq do Centro de Artes da Universidade Regional do Cariri - URCA.

Ao longo de nossa caminhada, iniciada em 2015, com o Projeto de Pesquisa Ensino de Artes Visuais e Escola sem Homofobia, em desenvolvimento até o momento, e em 2018 com o Projeto de Pesquisa Gay power, ensino de artes visuais e utopias pedagógicas na América Latina, temos nos debruçado sobre uma embrionária bibliografia que trata da relação entre arte e homossexualidade, arte gay ou arte e cultura queer. Além de embrionária, essa bibliografia se concentra na Europa e nos Estados Unidos, o que aponta para a necessidade de estudos e pesquisas que se voltem para a temática com recortes para o contexto latino-americano.

Nosso objetivo tem sido o de decolonializar o ensino de Arte no contexto da escola de Educação Básica, especificamente, o ensino das artes visuais. Em um

\footnotetext{
1 Ver: https://bndigital.bn.gov.br/exposicoes/alair-gomes-muito-prazer/introducaoalairgomes/. Acesso em: 15 nov. 2018. 


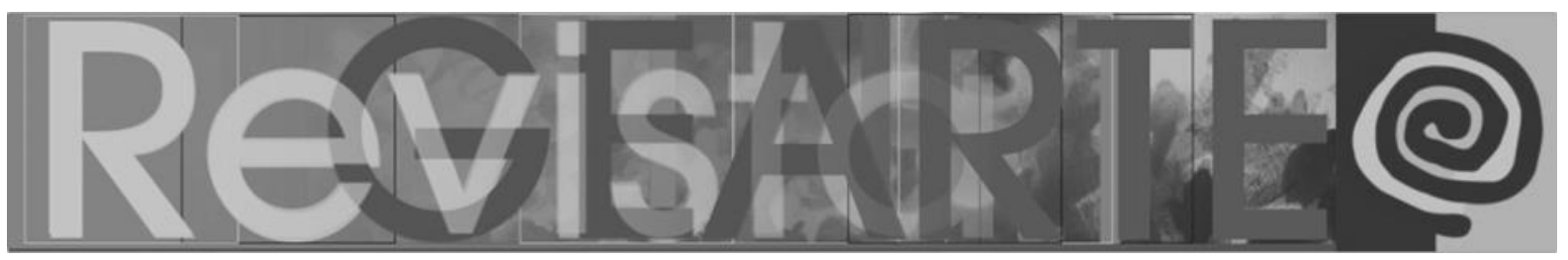

primeiro momento, entendíamos que a decolonialidade ocorreria por meio da inserção de artistas ativistas e artivistas LGBT na seleção das/os professoras/es.

Entretanto, muito rapidamente nos demos conta de que esta inserção não assegura um projeto educativo emancipatório. Isso porque o pensamento das professoras e dos professores tem sido colonizado muito antes de ingressarem nos cursos de formação inicial, temos sido colonizadas e colonizados ao longo da vida. Portanto, nossa colonização também ocorre nos cursos de licenciatura e prosseguem quando de nosso ingresso nas redes de ensino (municipal, estadual e federal) como profissionais da educação.

Nos últimos anos, presenciamos professoras e professores que, ao tomarem para si uma orientação religiosa, usam dessa orientação para reproduzir modelos de colonialidade ao negarem as relações entre sexos, gêneros e sexualidades. Ao usarem de abordagens religiosas insistem que ser lésbica, gay, bissexual, travesti e transexual são desvios da sociedade atual. Deste modo, desconhecem ou negam que a população LGBT tem história, e esta história se escreve ao longo da própria história da humanidade.

A história das homossexualidades, tratada desde uma concepção conservadora, não será capaz de admitir que a população LGBT de hoje seja o resultado de séculos de invisibilidade, exclusões, negação de direitos, de extermínios, assim como, de que essa população encontrou no final dos anos de 1960 as condições concretas para levantes, denúncias e organização em diferentes países. Portanto, essa história deve ser analisada - como defendem Peter Fry e Edward Macrae -, "no campo do estudo da cultura e da política no seu sentido mais amplo" (1984, p. 10). Para Hiro Okita (2007, p. 21): "A verdade sobre a homossexualidade, bem como suas origens e a história do preconceito anti-homossexual, tem sido escondida e deturpada perante a sociedade".

Hoje, denunciamos a política anti-lgbt, pois, na atualidade, reivindicamo-nos como lésbicas, gays, bissexuais, travestis e transexuais. Esses são nossos lugares 


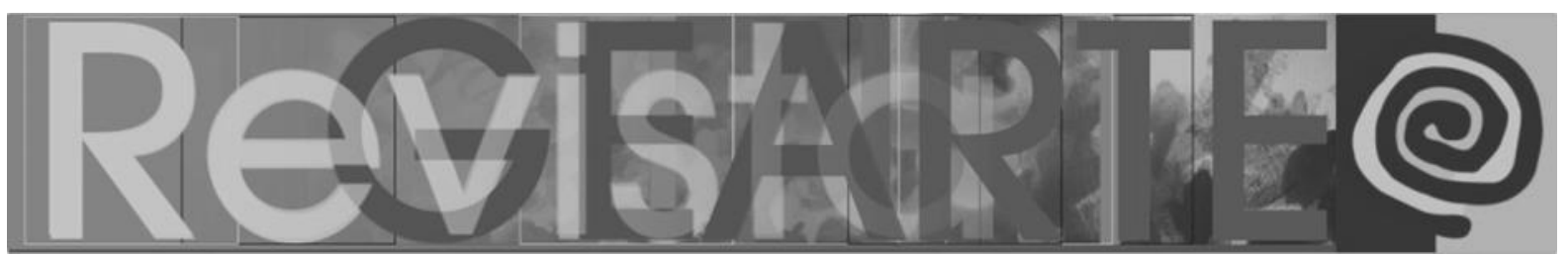

atuais de identidades, pertencimentos, lutas e resistências. Digo atuais, porque acredito que nosso horizonte emancipatório objetive que as homossexualidades sejam consideradas "como uma forma de sexualidade tão legítima quanto a heterossexualidade", como afirma Daniel Borrillo (2010, p. 14). Mas, reconheço que a construção desse horizonte seja uma empreitada das mais difíceis, uma vez que nos guiamos pelos imaginários europeus introduzidos na América a partir dos anos finais do século XV. Não podemos ignorar os 526 anos da América marcados pela colonização advinda da Europa e, posteriormente de uma colonialidade das elites econômicas internas comprometidas com o capital internacional.

Santiago Castro-Gómez (2005, p. 58) ajuda-me a afirmar que a América, e nela a América Latina, foi sequestrada pela modernidade/colonialidade caracterizada pela "colonialidade do poder" - categoria desenvolvida por Aníbal Quijano (1928-2018) - a partir do controle da subjetividade, numa biopolítica centrada na dimensão racial e na dimensão epistêmica "mostrando que el dominio que garantiza la reproducción incesante del capital en las sociedades modernas pasa, necesariamente, por la occidentalización del imaginário".

Se hoje promovemos um amplo debate que tem desestabilizado as concepções de sexos, gêneros e sexualidades é porque o projeto histórico da modernidade/colonialidade nunca foi nosso horizonte. Nesse projeto tentaram por diversas vias nos convencer da "naturalização" da sexualidade, como analisado por Guacira Lopes Louro (2018), cuja justificativa orbitou na relação entre corpo e sexualidade e em um corpo de mulher e de homem, no qual a sexualidade já foi previamente fixada. Louro se contrapõe a essa concepção, pois entende que a "sexualidade envolve rituais, linguagens, fantasias, representações, símbolos, convenções... Processos profundamente culturais e plurais" (LOURO, 2018, p. 12).

Os conquistadores chegaram à América em 1492 com um saber oriundo do direito romano e canônico. Não me refiro aqui de que maneira Grécia e Roma 


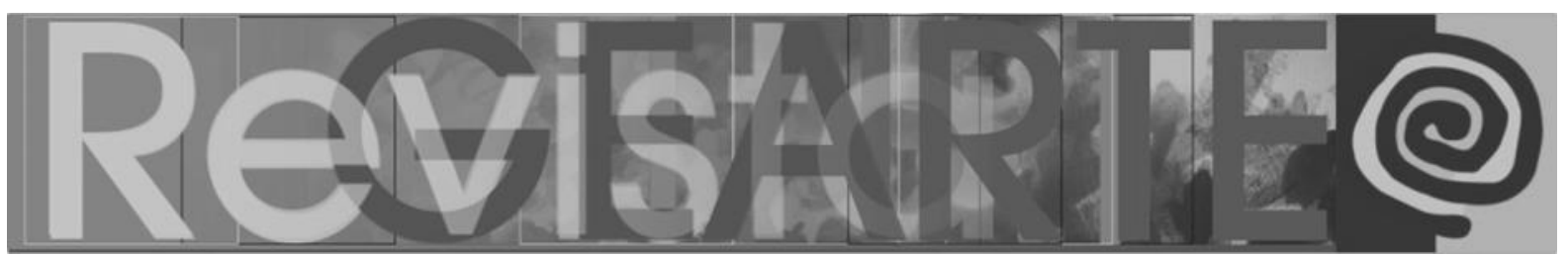

separavam o público do privado quando o assunto eram as práticas sexuais ${ }^{2}$, incluindo o "amor grego" ou o "amor entre iguais". Refiro-me às regras e normas que a partir do século IV, quando Constantino proclamou o cristianismo como religião oficial do Império Romano tornando lei civil o que antes estava circunscrito ao clero, dando origem ao fim das liberdades individuais na Europa, como Osvaldo Bázan (2010).

A conquista da América não foi apenas territorial. Ela foi fundamentalmente epistêmica e de base religiosa judaico-cristã centrada nas ideias de Santo Agostinho (354-450)3 . Para ele em suas "Confissões" o prazer carnal era a permanência do pecado original e que praticar o sexo seria apenas para a reprodução. Ao definir a prática sexual entre homem e mulher com o objetivo de assegurar a procriação humana, condenava o prazer sexual e dava uma função para essa prática que seria apenas como descarga de sémen no ato sexual.

Sabemos que Santo Agostinho em suas confissões tratava de suas próprias angústias quanto à sua sexualidade, mas sabemos também que durante oito séculos influenciou o pensamento e as práticas repressivas da Igreja Católica em relação à vida privada das pessoas quanto às suas sexualidades. No século XIII outro nome que contribuirá para a consolidação dessa repressão será Santo Tomás de Aquino (1225-1274), através de seus escritos e, principalmente, por meio de sua Suma Teológica, afirmando que a prática sexual seria correta desde que não impedisse intencionalmente a procriação humana. A "Impudicia contra natura", segundo Aquino, seria a prática de relações sexuais entre pessoas do mesmo sexo, entre homens e

2 De acordo com Daniel Borrillo (2010, p. 47): "os romanos e os gregos consideravam totalmente normal que homens tivessem relações sexuais com outros homens e, também, com mulheres. A regra segundo a qual a virilidade consiste em assumir o papel ativo na relação sexual era comum à moral das duas civilizações. ${ }^{34}$ As dicotomias "marcho/fêmea", "ativo/passivo" definiam os papéis sociais, o acesso ao poder e a posição de cada indivíduo segundo seu gênero e sua classe."

3 Considerado o teólogo e filósofo mais influente do cristianismo, ao elaborar uma teoria na qual separava a alma do corpo criando assim a culpa frente ao sexo, pois considerava que somos descendentes do pecado original de Adão e Eva e, portanto, o reproduzíamos, os argumentos para assegurar a dominação pela força aplicando castigos aos que se enquadravam nessa concepção de pecado. 


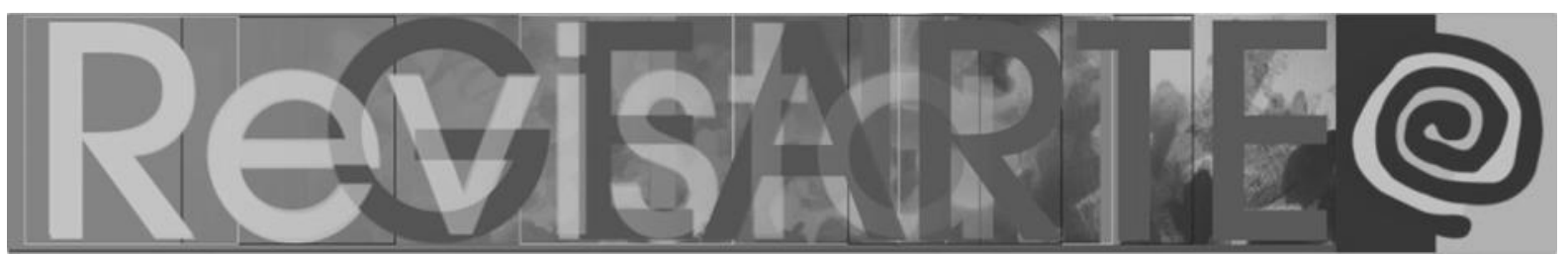

mulheres quando impedisse a procriação, ou entre um homem e um animal. Essas práticas sexuais deveriam ser freadas e punidas. ${ }^{4}$

Séculos de repressão, as sexualidades construíram o pensamento dos conquistadores que desembarcaram na América que, segundo Bázan (2010, p. 1112):

Con esa carga moral impresa en sus genes, los orgullosos aventureros de la Marigalante, malolientes, con tejidos de lana y terciopelo que rehusaron abandonar hasta en el tórrido Caribe, solo porque venían "de un país donde se producía una de las mejores lanas del mundo", 5 se encontraron con indígenas desnudos. Mientras los españoles decían que solamente había que tener sexo para engendrar hijos, los anahuacas, indígenas de La Española, no habían llegado a relacionar la idea del coito con la de reproducción.

As interpretações dadas ao suposto fenômeno ocorrido nas cidades de Sodoma e Gomorra, relatadas na Bíblia ${ }^{5}$, foi transformado em argumentos para reprimir o corpo, o sexo e a sexualidade na Europa. O amor entre iguais ou amor grego praticado mundo afora foi concentrado na cidade de Sodoma, como se só nessa cidade existisse, e que a ira de Deus sobre ela tivesse ocorrido pela vida sexual de seus moradores e, especialmente, dos homens dessa cidade. As interpretações deram origem ao sodomita como aquele pecador que pratica a sodomia e a sodomia é o ato sexual entre dois homens. Os sodomitas estariam desperdiçando a "semente do homem", como destaca Luiz Mott: "A cultura ocidental herdou da tradição judaicocristã uma forte intolerância, verdadeiro tabu, quase uma superstição em relação ao

4 "A Escolástica vai construir, assim, uma norma que continua modelando a ideologia sexual ocidental: o coito heterossexual do tipo conjugal e a submissão da mulher na relação sexual, cujo único objetivo consiste na inseminação procriadora. Mas, sobretudo, ela dará forma a uma homofobia, difusa na época, ao comparar as relações homossexuais aos pecados mais abjetos, tais como canibalismo, bestialidade ou ingestão de imundícies (II a II ae, q. 142, 4, 32)." (BORRILLO, 2010, p. 53)

5 Para Borrillo (2010) contextualizar os escritos bíblicos nos ajuda a compreender o porquê de tanta crueldade expressa ao tratar das práticas sexuais entre homens: "após sua libertação do Egito, o povo de Israel foi obrigado a editar normas estritas, destinadas a garantir sua sobrevivência demográfica e cultural. Os alicerces patriarcais do povo judeu encontrar-se-iam, efetivamente, em perigo se viessem a disseminar-se outras práticas além da relação com mulheres. Essa dupla necessidade - preservação biológica da comunidade dos eleitos e conservação cultural da sociedade patriarcal - explica a hostilidade contra as práticas homossexuais." (p. 49) 


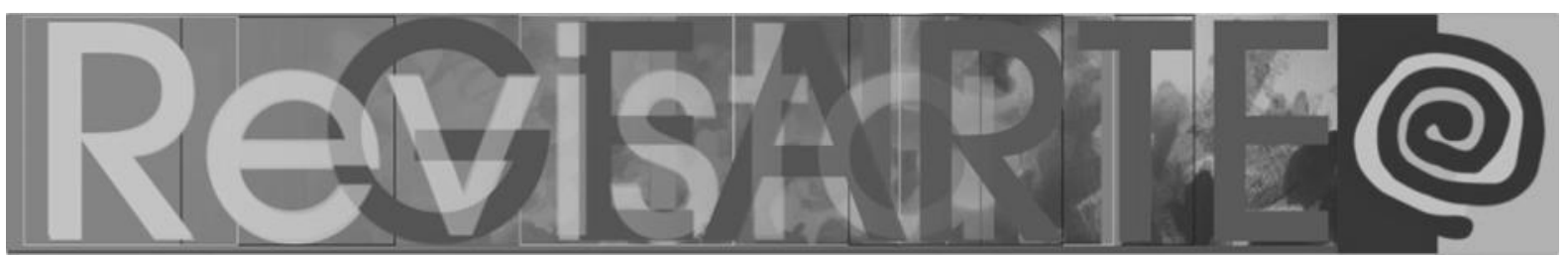

esperma - a semente do homem - termo encontrado em diversos processos da Inquisição Portuguesa." (2001, p. 189) 6

Para Santos:

a criação de normas para este pecado-crime pode ser compreendida como uma espécie de proteção à cristandade, sendo definidas não apenas nas Partidas, mas já em códigos anteriores, como é possível perceber na leitura do Fuero Real ${ }^{4}$, redigido entre 1251 e 1254 - iniciado por Fernando III e finalizada com Afonso $X$-, com o objetivo de substituir os direitos consuetudinários do reino por um fuero único. (p. 6)

Bazán (2010) destaca que o Papa Inocêncio III (1198-1216) foi responsável por uma repressão aos hereges e dentro desta categoria incluía-se os sodomitas. Já em 1231 é instalado o Tribunal da Inquisição ("Santo Ofício") em Roma e os primeiros acusados de crime são os sodomitas brancos, pois "violaban el plan de Dios, desperdiciando su simiente por una vida estéril, lo que los convertía en perversos dignos del máximo castigo.5" (p. 14).

E o máximo castigo fica expresso na legislação inglesa do século XII para as pessoas que praticavam sexo com judeus, crianças e pessoas de seu próprio sexo. Como castigo, seriam enterradas vivas (BAZÁN, 2010). Em 1497, cinco anos após a chegada dos primeiros conquistadores à América, "los Reyes Católicos, Fernando de Aragón e Isabel de Castilla, dispusieron la muerte en la hoguera para los responsables del acto de "sodomía" o "pecado nefando contra natura". ${ }^{7}$ (BAZÁN, 2010, p. 15)

Trevisan (2018) elenca as inúmeras punições que foram atribuídas aos sodomitas ao longo dos séculos XVI, XVII e XVIII na Europa católica e protestante:

Seus praticantes eram condenados a punições capazes de desafiar as imaginações mais sádicas, variando historicamente desde multas, prisão,

6 Ainda sobre a "semente de homem", Mott acrescenta "O líquido seminal é chamado, na maioria das línguas ocidentais, ora de esperma, termo proveniente do grego, ora do latim sêmen, ambos significando semente. No português, aparecem ambas as expressões nos livros de medicina, desde o século XV, datando de 1564 o mais antigo documento por nós encontrado no Arquivo da Torre do Tombo, onde vem manuscrito sperma. ${ }^{1}$ Sêmen e esperma sempre foram termos eruditos, restritos aos manuais de medicina e de teologia moral, pois nossos antepassados denominavam tal líquido de semente de homem, popularmente também referido como leite e leitaço. ${ }^{2 "}(2001$, p. 190)

COSTA, Fábio José Rodrigues da. Ensino/Aprendizagem das Artes Visuais na 203

América Latina: colonialidade cultural e emocional aliada a questões LGBT.

Revista GEARTE, Porto Alegre, v. 6, n. 2, p. 197-246, maio/ago. 2019.

Disponível em: http://seer.ufrgs.br/gearte 


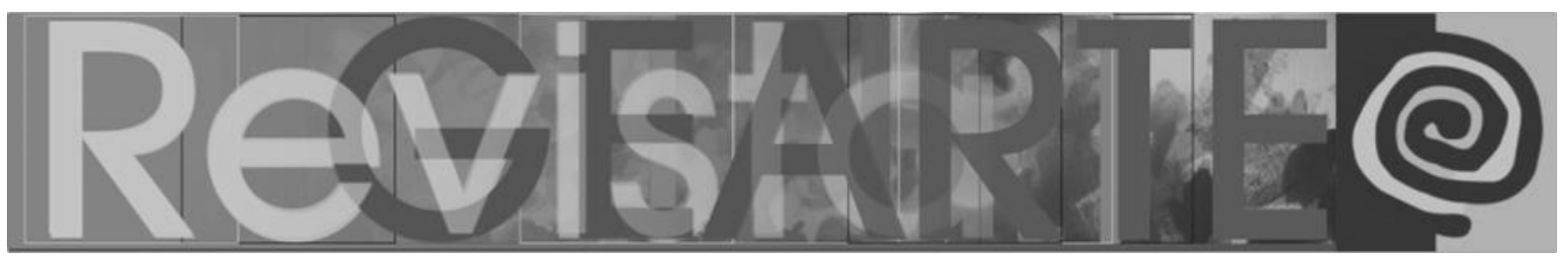

confisco de bens, banimento da cidade ou do país, trabalho forçado (nas galés ou não), passando por marca com ferro em brasa, execração e açoite público até a castração, amputação das orelhas, morte na forca, morte por fogueira, empalhamento e afogamento. Entre as vítimas, podiam-se contar tanto nobres, eclesiásticos, universitários e marinheiros quanto simples camponeses, servos e artesãos. ${ }^{1}$ (2018, p. 132)

A Europa criou identidades e dentre elas a do sodomita. Ao criar esta identidade também criou dispositivos para enquadrar os próprios europeus e depois tornou esse conhecimento em um de seus tentáculos de seu projeto imperial/colonial, como analisa Mignolo: um projeto a partir de uma "geo-política e a política de Estado de pessoas, línguas, religiões, conceitos políticos e econômicos, subjetividades, etc., que foram racializadas - ou seja, sua óbvia humanidade foi negada." (MIGNOLO, 2008, p. 290). A razão imperial/colonial afirmou-se "como uma identidade superior ao construir construtos inferiores (raciais, nacionais, religiosos, sexuais, de gênero), e de expelilos para fora da esfera normativa do "real". (MIGNOLO, 2008, p. 291).

O autor defenderá a decolonialidade ou a opção decolonial a partir do "aprender a desaprender", como estratégia para que nós, latino-americanas e latino-americanos, possamos aprender a desaprender sobre nós mesmos como condição para a construção de um projeto emancipatório.

Pensar o ensino de Arte/Artes Visuais requer pensar também o conhecimento das professoras e professores, e pensar sobre o conhecimento acumulado por estas e estes profissionais da educação, aponta para um exercício de aprender a desaprender. 


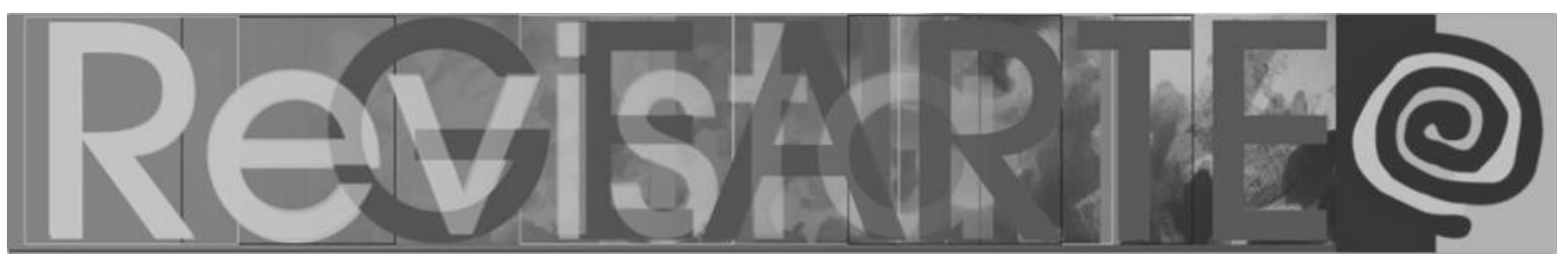

\section{Aprender a desaprender - praticantes de lá e praticantes de cá; primeira desobediência epistêmica}

De todas as coisas da vida que proibiram aos gays, a adolescência é a mais injusta. (BIMBI, 2017, p. 12).

Vamos iniciar esse nosso exercício como professoras e professores de Arte das duas esferas de organização do sistema educacional brasileiro: aquelas e aqueles que atuam na educação básica e aquelas e aqueles que atuam na educação superior ou universitária, tomando como ponto de partida as eleições de 2018, a qual teve um crescimento de aproximadamente $400 \%$ no número de candidatas e candidatos LGBT (lésbica, gay, bissexual, travesti e transexual) aos cargos de deputado estadual, governador, deputado federal e senador. Esse aumento ocorre exatamente dentro de uma das eleições mais conservadoras que a recente democracia brasileira vivencia. Basta lembrar que o candidato eleito a presidência do nosso país é o principal opositor das bandeiras defendidas pela população LGBT, promotor do discurso de ódio a esta mesma população e representante da extrema-direita brasileira.

O aumento no número de candidatas/os nas eleições de 2018 é uma clara demonstração de que não aceitamos um Estado Democrático de Direito sem a legitima presença de representantes dos diferentes segmentos sociais de nosso país. O Brasil tem ocupado a primeira posição dentre os países da América Latina a eleger gays e transexuais para cargos públicos, mas nem todas/os eleitas/os estiveram orientadas/os nas pautas defendidas e reivindicadas por esta população, a exemplo da igualdade de gênero, casamento civil e criminalização da LGBTfobia, para citar alguns.

No Brasil, em 1992, a cidade de Colônia do Piauí/PI, um dos nove estados da Região Nordeste, elegeu a primeira vereadora transexual - Kátia Tapey - que foi reeleita em 1996 e em 2000. Em 2004 foi eleita vice-prefeita da cidade. Em 2006 o estado de São Paulo elege Clodovil Hernandes o primeiro deputado federal gay. Em 2008 a cidade de Salvador/BA elege seu primeiro vereador gay e em 2010 o estado 


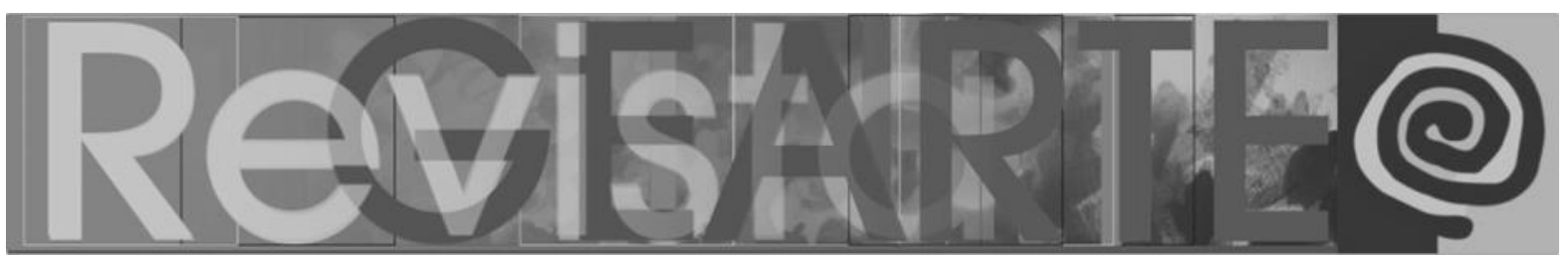

do Rio de Janeiro elege seu primeiro deputado federal gay, Jean Wyllys, sendo reeleito em 2014 e 2018.

No contexto dos demais países latino-americanos, o México elegeu sua primeira deputada federal lésbica em 1997; a Colômbia elegeu seu primeiro prefeito gay em 1988 e a primeira senadora lésbica em 2014; o Chile elegeu para vereadora sua primeira transexual em 2004; o Peru elegeu seu primeiro senador gay em 2006; a Costa Rica elegeu sua primeira deputada lésbica em 2010; a Argentina elegeu seu primeiro senador gay em 2011; a Bolívia elegeu seu primeiro deputado gay em 2014; a Guatemala elegeu sua primeira deputada lésbica em 2015; a Venezuela elegeu seu primeiro deputado federal gay em 2015 e sua primeira deputada transexual no mesmo ano; o Uruguai elegeu sua primeira senadora transexual em 2017.

Considero que a população LGBT latino-americana se aproxime, nesse momento histórico, da desobediência epistêmica, reafirmando a identidade em política tratada por Mignolo (2008), ao definir a identidade em política como

\begin{abstract}
a única maneira de pensar descolonialmente (o que significa pensar politicamente em termos e projetos de descolonização). Todas as outras formas de pensar (ou seja, que interferem com a organização do conhecimento e da compreensão) e de agir politicamente, ou seja, formas que não são descoloniais, significam permanecer na razão imperial; ou seja, dentro da política imperial de identidades. (MIGNOLO, 2008, p. 290)
\end{abstract}

Essa política imperial/colonial de identidades deu lugar ao índio e aos sodomitas que não existiam na América até 1492; como também não existia negro antes do comércio de escravos no Atlântico. Essas identidades foram construídas, segundo Mignolo (2008, p. 289-290), "pelos discursos europeus modernos" que "eram raciais (isto é, a matriz racial colonial) e patriarcais."

Essa ocidentalização do imaginário chega à América a partir de 1492 com os primeiros europeus, chefiados por Cristóvão Colombo. Para o historiador francês, Serge Gruzinski (2006):

o Almirante descobre homens de corpos nus e pintados, que acreditam que os espanhóis são criaturas vindas do céu. Saindo dos sonhos e das lendas 


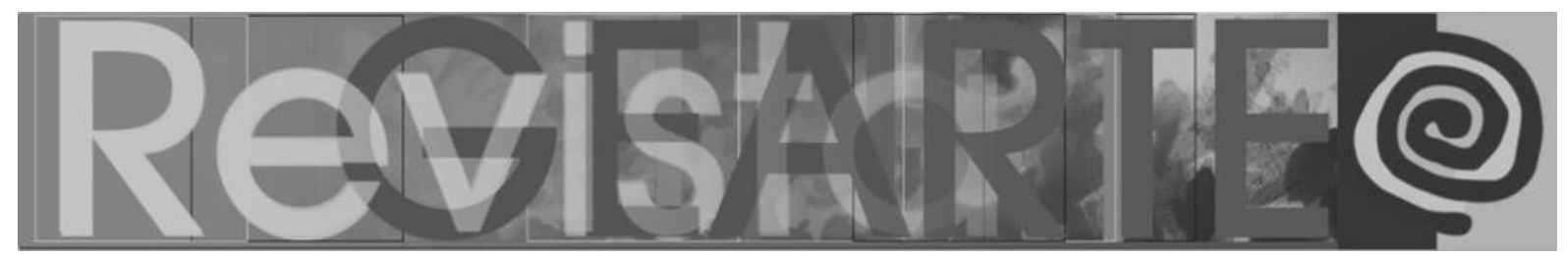

que povoavam sua imaginação, Colombo e seus companheiros se encontram diante de "gente muito pobre de tudo". Entretanto, aquela gente possui alguns objetos que atraem o olhar do Almirante. Basta isso para que se inicie uma outra descoberta, por onde se embrenha a sensibilidade de um genovês do século XV, como se o olho do Quatrocentos fosse o primeiro a pousar sobre a América (GRUZINSKI, 2006, p. 25)

E o olho do Quatrocentos advém "de uma Itália renascentista onde fazia quase um século que os artistas multiplicavam os "objetos de civilização", figurativos e profanos, sem parar de reproduzir um leque considerável de representações religiosas" (GRUZINSKI, 2006, p. 27). O olho se dirige na busca de comparação entre os referenciais europeus e aquelas visualidades (Figuras 1 e 2) que em nada se aproximavam das já conhecidas culturas pelos conquistadores.

Figura 1 - Deity Figure (Zemi), Artefato taínico. República Dominicana. Madeira.

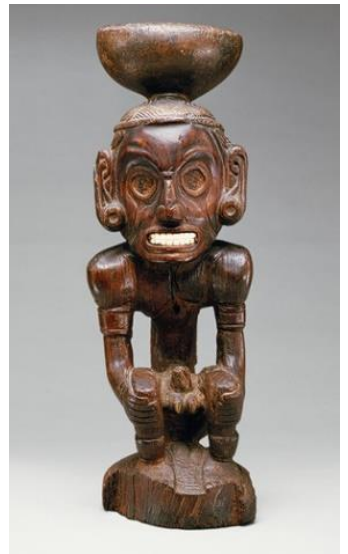

Fonte: Metropolitan Museum of Art. New York. ${ }^{7}$

7 Disponível em: <http://www.metmuseum.org/toah/ho/08/canc/ho_1979.206.380.htm (October 2006)>. Acesso em: 15 nov. 2018. 


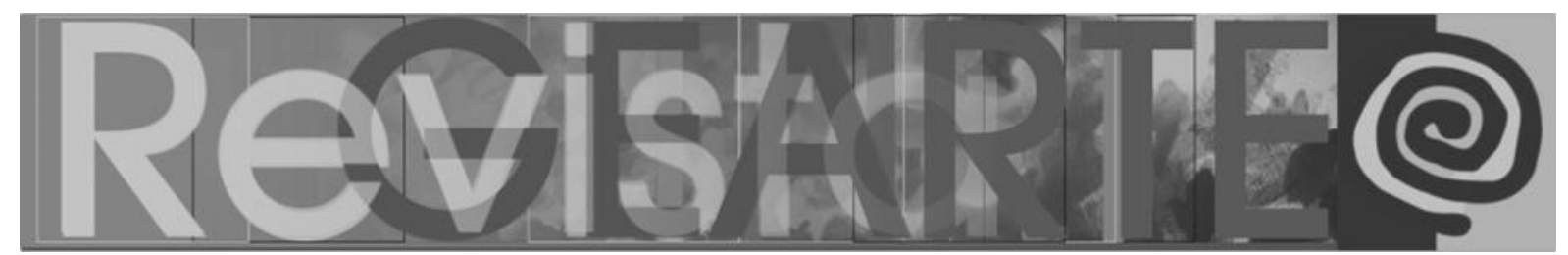

Figura 2 - Artefato taínico da República Dominicana

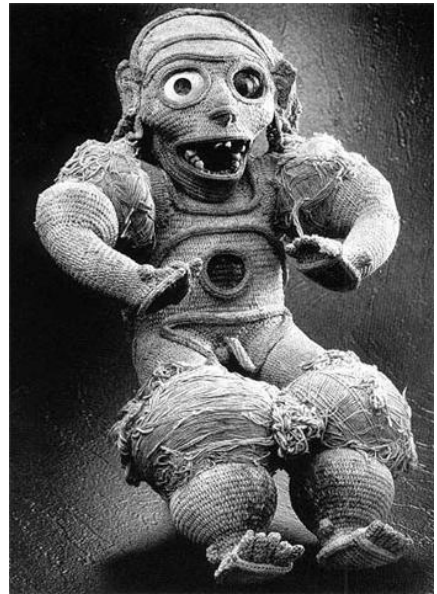

Fonte: Blog.goldenkeymanagement.com. ${ }^{8}$

Esses objetos (cemíes ou zeme) serão analisados à luz do pensamento europeu, tanto dos que invadiam as primeiras ilhas da América, como serão enviados para a Europa e lá serão julgados por homens que nunca estiveram no que viria a ser chamado de "Novo Mundo". Essa prática também será usada pelo padre e historiador espanhol Francisco López de Gómara (1511-1566), que, embora nunca tenha saído da Europa, é autor da História Geral das Índias (1552).

Bázan destaca que a História Geral das Índias era "un códice en donde con consternación y verdadero asco registra una y otra vez la presencia de la 'sodomía' en las tribus indígenas" (2010, p. 10).

Quem, além dos europeus, sabia na América a interpretação dada ao termo sodomita? Quem, além dos europeus, sabia na América o significado de "crime contra natura"? Quem, além dos europeus, sabia na América da existência do Antigo Testamento, da Bíblia, dos escritos de Santo Agostinho e de Santo Tomás de Aquino? Quem, além dos europeus, sabia na América do Santo Ofício e da Inquisição? Todo um aparato epistêmico chegou com os conquistadores, o que reforça a tese do

8 Disponível em: <http://blog.goldenkeymanagement.com/2014/09/tainos-dominican-republic-1492/>. Acesso em: 15 nov. 2018. 


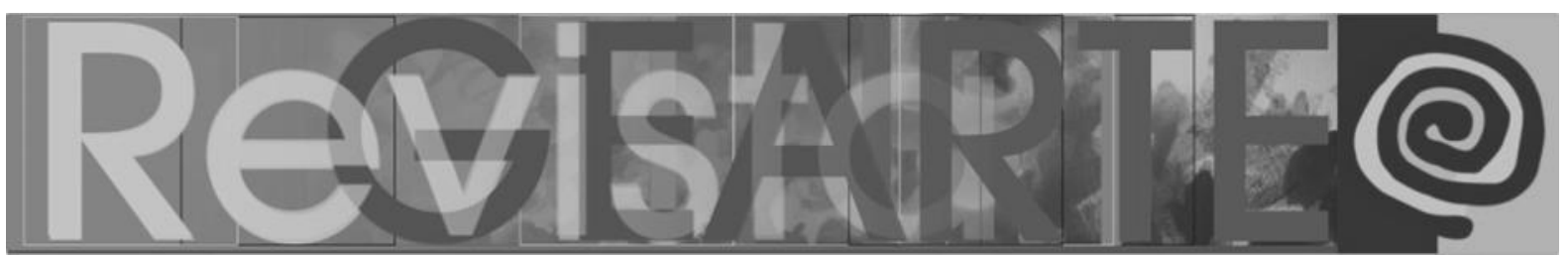

sociólogo peruano Aníbal Quijano sobre a colonialidade do poder, como afirma Castro-Gómez (2005, p. 58):

La «colonialidad del poder» hace referencia, inicialmente, a una estructura específica de dominación a través de la cual fueron sometidas las poblaciones nativas de América a partir de 1492. Aníbal Quijano, quien utilizó por primera vez la categoría, afirmó que los colonizadores españoles entablaron con los colonizados amerindios una relación de poder fundada en la superioridad étnica y epistémica de los primeros sobre los segundos. No se trataba tan sólo de someter militarmente a los indígenas y destruirlos por la fuerza sino de transformar su alma, de lograr que cambiaran radicalmente sus formas tradicionales de conocer el mundo y de conocerse a sí mismos, adoptando como propio el universo cognitivo del colonizador.

E no universo cognitivo do colonizador estava uma clara definição de gênero, pois, segundo Bázan (2010), nos primeiros dez anos do século XVI, na cronologia europeia, houve a primeira matança de "homossexuais" que se tem registro na América, e eles eram indígenas. "Realizamos um ato de purificação", justificaram os espanhóis, porém os mortos eram homens que usavam "roupa de mulher".

Los españoles solo vieron lo que conocían: estos hombres en ropas que los conquistadores supusieron "de mujer" desafiaban toda la construcción ética y moral que traían de la España oscurantista. Necesariamente, para los europeos del siglo XVI, hombres en "enaguas" eran "sodomitas". No tenían otra palabra para calificarlos. Y el orden social y religioso que los abarcaba les había enseñado muy bien cómo tratarlos. (BÁZAN, 2010, p. 17)

Para Castro-Gómez (2005), a primeira característica da colonialidade do poder foram as estratégias utilizadas para que os dominados "naturalizaran el imaginario cultural europeo como forma única de relacionamiento con la naturaleza, con el mundo social y con la propia subjetividad." Portanto, para o autor, foi um "proyecto sui generis quiso cambiar radicalmente las estructuras cognitivas, afectivas y volitivas del dominado, es decir, convertirlo en un 'nuevo hombre', hecho a imagen y semejanza del hombre occidental" (CASTRO-GÓMEZ, 2005, p. 59).

A matança dos homens que vestiam "roupa de mulher" é um claro exemplo do significado dado pelos espanhóis ao termo "sodomita" e de que "ser diferentes a lo que los conquistadores esperaban de un hombre les valió el castigo" (BAZÁN, 2004, 


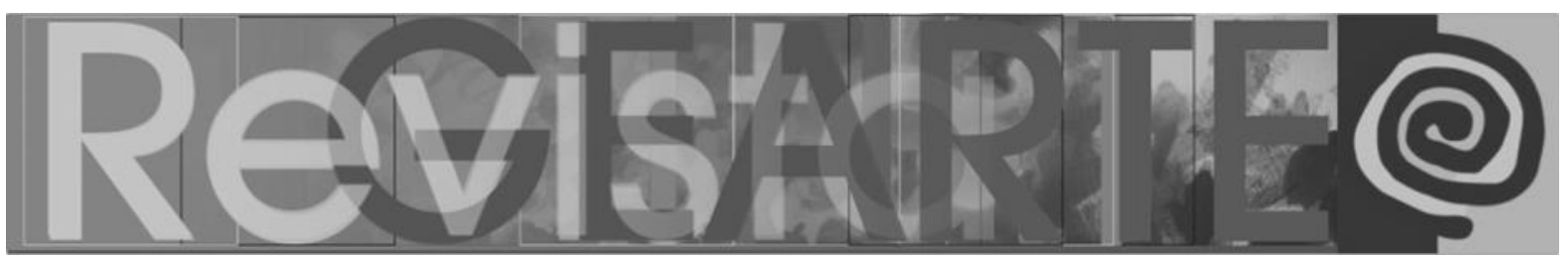

p. 18). Nesse sentido, a tese de Mignolo de que a América foi vista como um prolongamento natural da Europa, como destaca Castro-Gómez, nos parece evidente:

Este aspecto se relaciona con lo señalado por Mignolo en el sentido de que América fue vista como la prolongación natural de Europa. Para lograr este objetivo civilizador el Estado español creó la encomienda, cuya función fue integrar al indio a los patrones culturales de la etnia dominante. El papel del encomendero era velar, diligentemente, por la «conversión integral» del indio mediante la evangelización sistemática y el duro trabajo corporal. Ambos instrumentos, la evangelización y el trabajo, se dirigían hacia la transformación de la intimidad, buscando que el indio pudiera salir de su condición de «menor de edad» y acceder, finalmente, a los modos de pensamiento y acción propios de la vida civilizada. (CASTRO-GÓMEZ, 2005, p. 59).

Mas, é necessário estabelecer conexões para outras evidências que modificariam profundamente o imaginário europeu e que, também, terão consequências na conquista da América: 1) a invenção da imprensa em 1439 por Johannes Gensfleisch zur Laden zum Gutenberg, mais conhecido por Johannes Gutenberg (1400-1468); 2) a invasão e conquista da América, a partir de 1492 por Cristóvão Colombo (1451-1506); e a Reforma Protestante de Martinho Lutero (14831546), com a publicação das suas 95 teses em 1517.

Em 1594, surge na Europa a primeira imagem do castigo aplicado aos sodomitas do Novo Mundo (Figura 3) com a gravura de Théodore de Bry (1528-1598), um protestante calvinista nascido na Bélgica que fugiu para a Alemanha logo após às perseguições dos católicos espanhóis. A gravura ilustrava os relatos que chegavam à Europa sobre a existência da sodomia e dos castigos aplicados pelos conquistadores aos indígenas sodomitas e pecadores.

9 Deolinda de Jesus Freire em seu ensaio Theodor de Bry e a narrativa visual da Brevísima Relación de la Destruición de las Indias publicado pela Revista USP em 2008, destaca que "Um dos motivos que explicam o interesse editorial de De Bry pelos relatos do Novo Mundo deve-se ao fato de a procura por esses relatos ter aumentado nas regiões fora da Península lbérica na segunda metade do século XVI. Tal fato ampliou, vertiginosamente, o público leitor, que, na primeira metade do século $\mathrm{XVI}$, estava restrito, principalmente, aos religiosos, às pessoas cultas e aos grandes comerciantes." (2008, p. 202-203). 


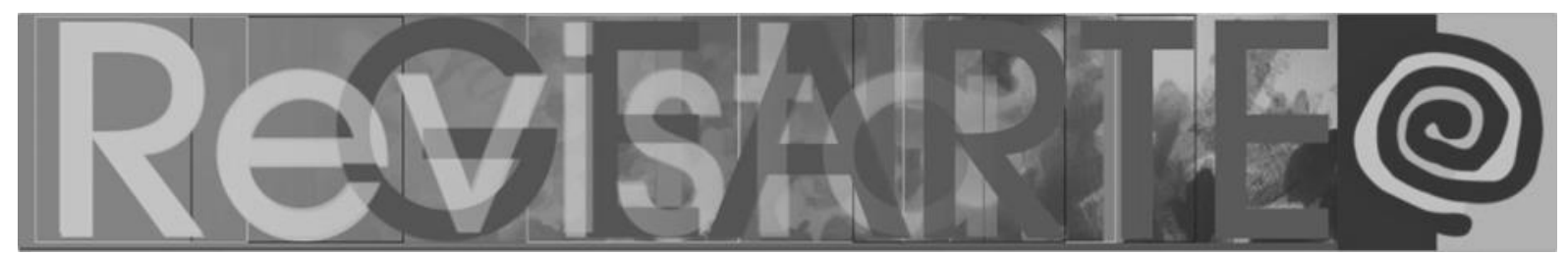

Figura 3 - Théodore de Bry, Balboa envía sus perros sobre indígenas practicantes de amor masculino. Gravura, 1594

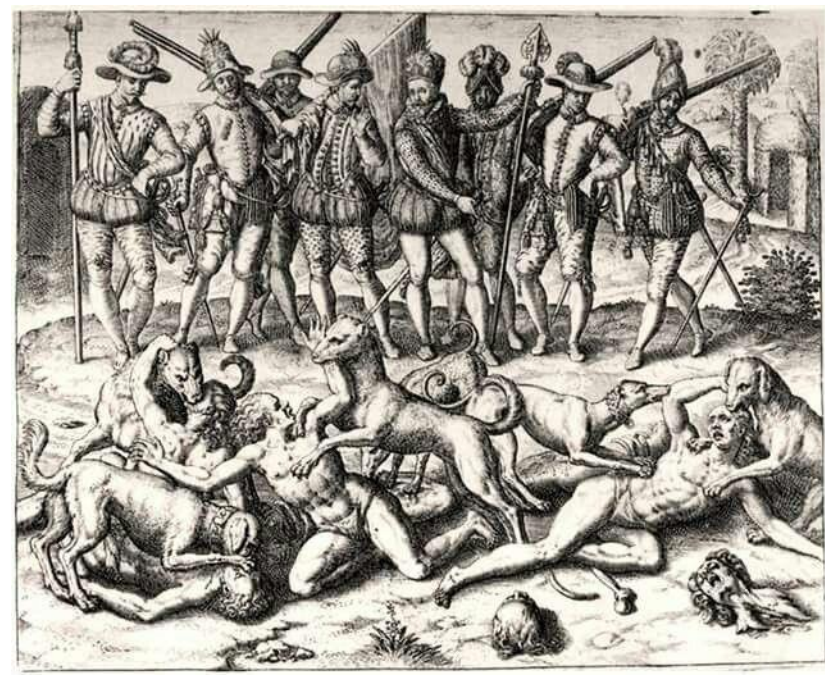

Fonte: Telesurtv. ${ }^{10}$

A gravura é o primeiro registro visual que confirma a prática sexual entre homens indígenas do Novo Mundo, bem como, nos ajuda a afirmar que esta prática sexual - coito anal - não era exclusividade dos europeus, mas ainda, ela nos revela que em mundos distintos, culturas distintas era uma prática sexual comum a todos os povos de nosso planeta. Para Gruzinski (2006) as intervenções dos conquistadores nos primeiros anos do século XVI não se caracterizaram em grandes destruições, mas a "mais brutal continua a ser, tudo indica, o massacre dos sodomitas perpetrado por Vasco Nuñez de Balboa." (GRUZINSKI, 2006, p. 54).

Embora o massacre tenha ocorrido em 1513 e sua ilustração, em 1594, o fato é que ocorreu e tem sido um dos testemunhos da ideia de que a América seria uma prolongação da Península lbérica e, digo da Península, porque já estavam em terras brasileiras os conquistadores portugueses. Mas, o que motivou os conquistadores a massacrarem os indígenas não teria sido apenas por se enquadrarem no conceito de sodomitas? A resposta a essa pergunta pode ser encontrada em Bázan (2010, p. 23) onde se lê:

10 Disponível em: <https://www.telesurtv.net/news/Memorias-del-holocausto-indigena-en-AmericaLatina-20160122-0074.html>. Acesso em: 15 nov. 2018. 


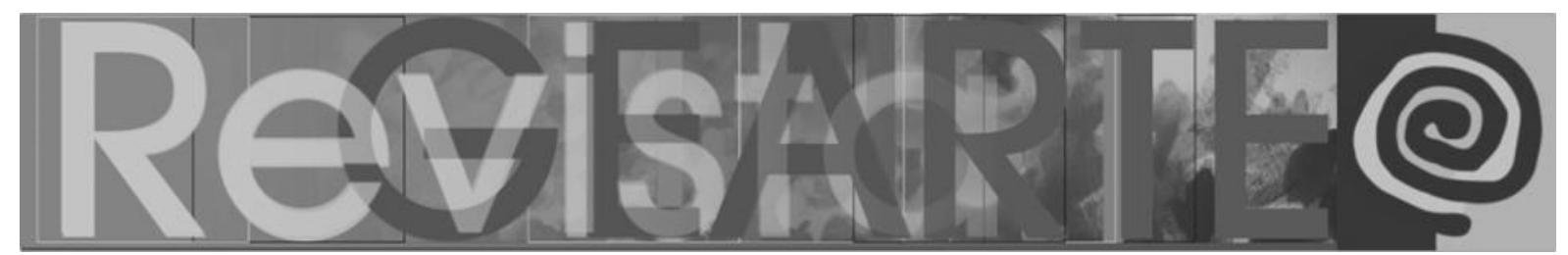

Unos meses antes, el astuto Panquiaco ${ }^{2}$, hijo del cacique Comagre, le había contado al ex polizón Vasco Núñez de Balboa, ya jefe de La Antigua, que al sur de las tierras en las que estaban había otro mar. Y que había oro en esas costas. En realidad, Panquiaco no podía entender por qué los españoles fundían las joyas bien labradas que les regalaban para hacer palitos dorados, y mucho menos por qué peleaban entre ellos por esos palitos. Viendo lo desesperados que estaban los españoles por oro y para sacárselos de encima, azuzó la codicia de los conquistadores: “¿Quieren oro? Vayan al sur". (BÁZAN, 2010, p. 23)

E Balboa seguiu em busca do ouro, e no caminho se deparou com outro grupo indígena, os Cuareca, liderados pelo cacique Torecha, que "quien no solo era tan desubicado para vivir pacíficamente con su pueblo en medio del paso de un mar a otro, sino que además quería que le pidieran permiso para transitar por sus tierras." (BÁZAN, 2010, p. 23).

Embora os Cuareca fossem em sua maioria superiores aos espanhóis, mais ou menos 600 indígenas que resistiram com seus arcos, flechas e macanas, os conquistadores usavam armas de fogo e mataram a todos, incluindo a Torecha. Em seguida, Balboa encontra na casa do cacique sobreviventes do massacre, o irmão e muitos outros, vestidos de mulher, os quais foram imediatamente atirados aos cachorros, como descrito:

También López de Gómara cuenta el hecho igualmente asombrado: "En esta batalla se toma preso al hermano de Torecha, en hábito real de mujer, que no solamente en el traje, pero en todo, salvo en parir, era hembra". ${ }^{4}$ Dos eran los acompañantes del hermano de Torecha que estaban, como él, vestidos con enaguas. El hecho de que se hubieran quedado en la casa mientras los demás hombres de la tribu habían ido a pelear y, más aún, que compartieran sin inconveniente la casa de la autoridad de la tribu, parece demostrar la falta de prejuicios de este grupo con respecto a la sexualidad de sus integrantes. Lamentablemente, esa falta de prejuicios no impregnó a los españoles de un espíritu más liberal. Ni mucho menos. Aferrado a su concepto de "pecado nefando", Vasco Núñez de Balboa apresó a cincuenta de estos "sodomitas" y les propinó un castigo bestial, muy a la usanza de la época: resolvió entregarlos a los perros hambrientos. (BÁZAN, 2010, p. 24)

O massacre desse grupo constituído agora em identidades - índios, primeiro e, depois, índios sodomitas, não significou o fim de ambos, mas a constatação de que a prática sexual entre homens permanecerá, tanto na Europa quanto na América espanhola e portuguesa. Na América Latina a sodomia será perseguida ao longo dos 


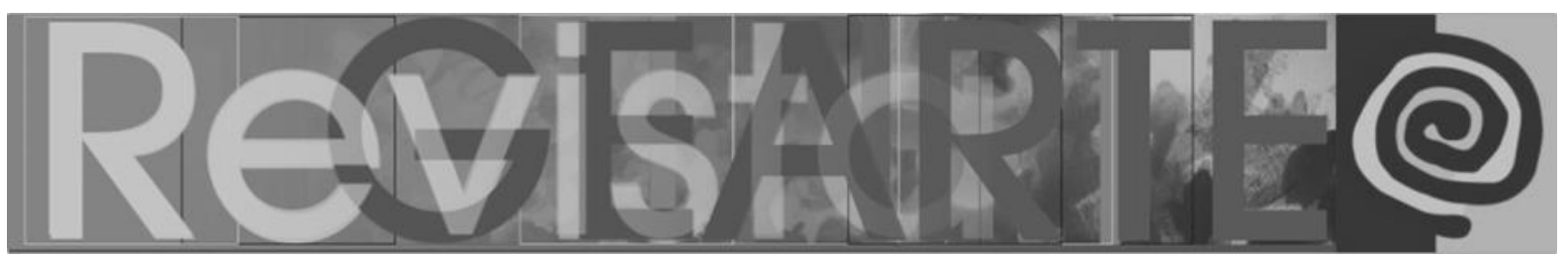

séculos XVI, XVII, XVIII e começos do XIX aos moldes da perseguição europeia, principalmente pela Inquisição, assombrada pela prática aqui realizada entre índios, brancos e negros.

No Brasil do século XVII, teremos dois casos de mortes registradas por sodomia, segundo Luiz Mott (2017) ${ }^{11}$. A primeira, ocorrida em 1613, em São Luís do Maranhão, quando um indígena Tupinambá foi amarrado à boca de um canhão e seu corpo destroçado, sob o pretexto de "purificação da terra da maldade" pelos conquistadores franceses e sob a orientação espiritual de monges capuchinhos. $\mathrm{O}$ outro caso ocorreu em 1678 na Capitania de Sergipe, quando um jovem negro escravo foi açoitado até a morte por ter cometido o pecado de sodomia.

As tentativas de exterminar os sodomitas, tanto na Europa quanto na América portuguesa por meio do conhecimento, da epistemologia imperial/colonial, surgiram a partir do século XVI com a instituição em Portugal do Tribunal do Santo Oficio da Inquisição em 1536 e extinto no século XIX, em 1821 (MOTT, 2001), tendo por objetivo "perseguir os hereges, aqueles que se opunham à verdadeira doutrina revelada por Jesus Cristo e oficializada pela Santa Madre Igreja. ${ }^{\text {" }}$ (MOTT, 2001, p. 191).

A vasta pesquisa realizada por Mott nos arquivos da Torre do Tombo revelou que ao longo dos séculos XVI e inícios do XIX um total de "4.419 homens, rapazes e meninos foram denunciados por diferentes práticas homoeróticas" (MOTT, 2001, p. 192) e desse número uns 447 se constituíram em denúncias que justificaram a abertura de processo formal, portanto, foram submetidos aos rigores do Tribunal, lembrando que só seriam queimados na fogueira aqueles que praticaram a sodomia perfeita $^{12}$, ou seja, "o esperma, matéria-prima do crime de sodomia, é presença

11 O artigo foi disponibilizado em PDF pela Universidade Federal de Pelotas - UFPel, porém se trate de uma comunicação do autor de 1994 apresentada no "Seminário-Taller de História de las Mentalidades y los Imaginarios", realizado na Pontíficia Universidad Javerina de Bogotá, Colômbia, Departamento de História e Geografia. <https://wp.ufpel.edu.br/ndh/files/2017/02/04.-Luiz_Mott.pdf>.

12 "Os Regimentos e os processos Inquisitoriais enfatizavam sempre que as Bulas Papais conferiam ao Santo Oficio tão-somente o poder de perseguir a sodomia perfeita, isto é, a penetração do membro viril desonesto no vaso traseiro, com derramação de sementes, não sendo de sua alçada 


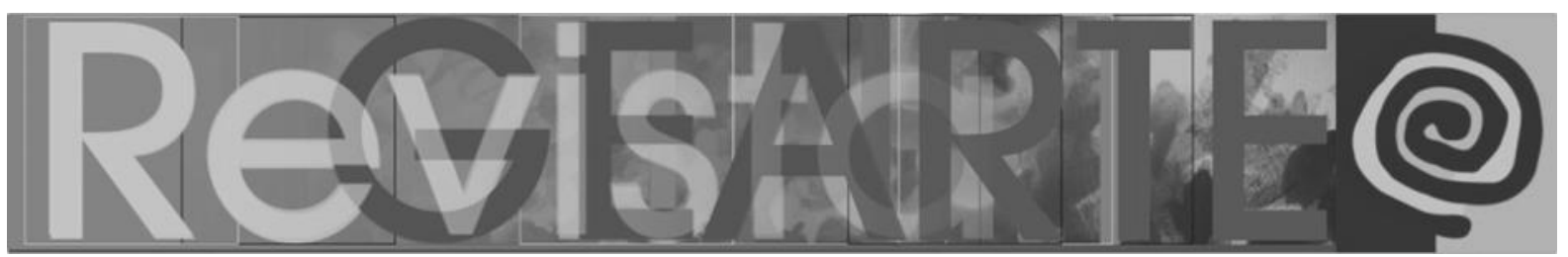

obrigatória, licor diabólico para os iracundos Inquisidores, néctar dos deuses para os amantes do mesmo sexo." (MOTT, 2001, p. 192)

De acordo com Trevisan (2018, p. 161), as Ordenações Manuelinas (1521) foi o mais antigo código penal aplicado no Brasil, pois vigoravam em Portugal à época do descobrimento" e equiparava a sodomia ao crime de lesa-majestade. "Além da pena de fogo, foi acrescentado como punição o confisco dos bens e a infâmia sobre os filhos e descendentes do condenado." Por trás de tanta crueldade existia um projeto imperial/colonial traduzido por Mott (2001), onde se lê:

A união livre dos homossexuais, desrespeitando as barreiras de raça, estamento e idade, parceria baseada tão-somente na paixão e mútua empatia, detonava a ordem familista patriarcal tradicional, daí o afinco com que os donos do poder colonial reprimiram os "filhos da dissidência". (MOTT, 2001, p. 59)

Em 1603, século XVII, foram editadas as Ordenações Filipinas, aplicadas até 1823, portanto, vigorando no Brasil até 25 de março de 1824, quando foi outorgada pelo Imperador D. Pedro I, a Constituição Política do Império do Brasil que descriminaliza a sodomia e ainda no "Titulo 8ำ- Das Disposições Geraes, e Garantias dos Direitos Civis, e Politicos dos Cidadãos Brazileiros, no artigo 179. A inviolabilidade dos Direitos Civis, e Politicos dos Cidadãos Brazileiros, que tem por base a liberdade, a segurança individual, e a propriedade", é garantida pela Constituição do Império, são abolidos os castigos e o repasse da culpa para os familiares como determinava as Ordenações Filipinas.

XIX. Desde já ficam abolidos os açoites, a tortura, a marca de ferro quente, e todas as mais penas crueis.

XX. Nenhuma pena passará da pessoa do delinquente. Por tanto não haverá em caso algum confiscação de bens, nem a infamia do Réo se transmitirá aos parentes em qualquer gráo, que seja.

os demais atos homoeróticos, tais como beijos, abraços, masturbação recíproca, cópula intrafemoral, conhecida popularmente como coxeta, nem mesmo o coitus interruptus homossexual e a felação. Embora todas essas variantes eróticas fossem consideradas pecados gravíssimos, merecedores do fogo do inferno, só era reconhecido como crime do conhecimento do Santo Ofício, este sim, merecedor da fogueira terrena, a ejaculação dentro do ânus." (MOTT, 2001, p. 191) 


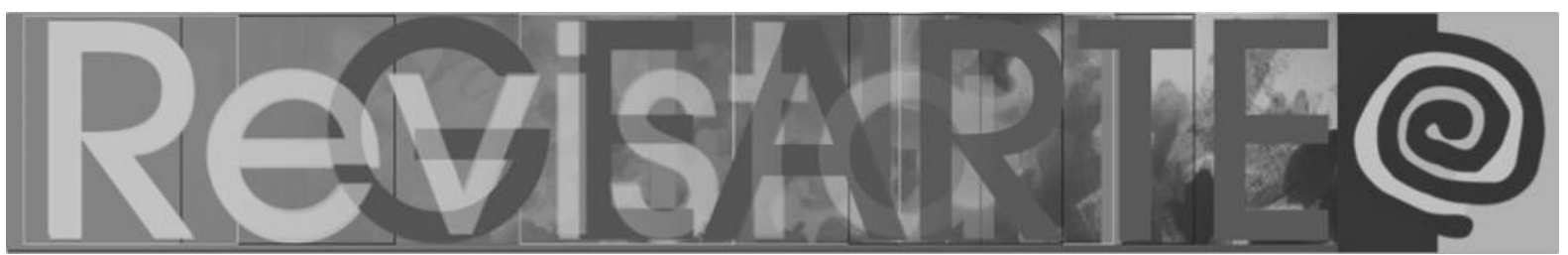

A Constituição de 1824, passa então a substituir as Ordenações Filipinas, que se aplicaram ao longo de dois séculos em Portugal e Brasil. Mas dois séculos de aprendizado, no qual se entendia a sodomia como pecado ${ }^{13}$, permanecerão no imaginário latino-americano e em nosso caso, brasileiro.

\title{
Aprender a desaprender - de sodomitas a homossexuais; segunda desobediência epistémica
}

\begin{abstract}
A busca das causas da homossexualidade, constitui, por si só, uma forma de homofobia (DORAIS, 1994), já que ela se baseia no preconceito que pressupõe a existência de uma sexualidade normal, acabada e completa, a saber: a heterossexualidade monogâmica em função da qual se deve interpretar e julgar todas as outras sexualidades. (BORRILLO, 2010, p. 71.)
\end{abstract}

"O futuro é dos Povos e não dos Impérios." Com esta afirmação Paulo Freire finaliza a carta publicada em seu livro "Pedagogia da indignação: cartas pedagógicas e outros escritos” (2000, p. 35). E tal afirmação se justifica no propósito da carta que foi escrita em 1992 atendendo a uma enquete da Fundação de Investigações Sociais e Políticas do Centro Ecumênico de Educação Popular de Buenos Aires sobre o V Centenário do Descobrimento da América. Na enquete transformada em carta, Freire nos diz que:

\begin{abstract}
O corpo e a alma da América, o corpo e a alma de seus povos originários, assim como o corpo e a alma dos homens e das mulheres que nasceram no chão americano, filhos e filhas de não importa de que combinações étnicas, o corpo e a alma de mulheres e homens que dizem não à dominação de um Estado sobre o outro, de um sexo sobre o outro, de uma classe social sobre a outra, sabem, o corpo e a alma dos progressistas e das progressistas, o que representou o processo de expansão europeia que trazia em si as limitações que nos eram impostas. E porque sabem não podem bem-dizer os invasores nem a invasão. Por isso mesmo é que a melhor maneira, não de festejar os 500 anos de invasão, não cruzando, porém, os braços diante dos festejos a eles feitos, seria homenagear a coragem, a rebeldia, a decisão de brigar, a bravura, a capacidade de lutar contra o invasor; a paixão pela liberdade, de índios e índias, de negros e negras, de brancos e brancas, de
\end{abstract}

13 "toda pessoa, de qualquer qualidade que seja, que pecado de sodomia por qualquer maneira cometer, seja queimado, e feito por fogo em pó, para que nunca de seu corpo e sepultura possa haver memória, e todos seus bens sejam confiscados para a Coroa de nosso Reino, posto que tenha descendentes; pelo mesmo caso seus filhos e netos ficarão inábiles e infames, assim como os daqueles que cometeram crime de Lesa Majestade.", extraído da página 161 do livro Devassos no Paraiso: a homossexualidade no Brasil, da colônia à atualidade", $4^{a}$ edição, 2018. 


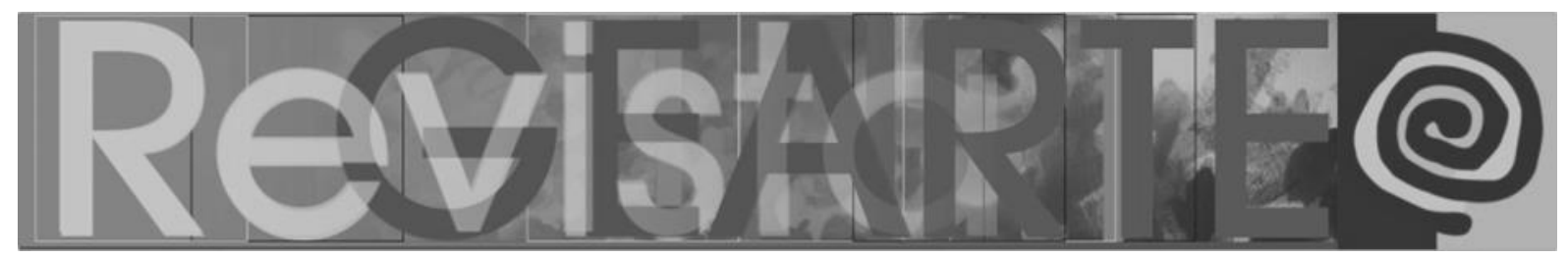

mamelucos, que tiveram seus corpos rasgados, seus sonhos despedaçados, suas vidas roubadas. (FREIRE, 2000, p. 34)

Todas as estratégias utilizadas pelos conquistadores da América, bem como, por seus descendentes, não foram suficientes para acabar com o amor entre homens e com a prática sexual entre eles, deste modo, a manutenção da expressão sodomia foi apagada dos instrumentos legais como as Constituições e os Códigos Penais em diferentes países da América Latina e também da Europa a partir do século XIX. Mott (2017) destaque que:

Com o fim das Inquisições Portuguesa e Espanhola, também na América Latina são extintos os Tribunais do Santo Ofício, em 1820 no Peru e México, em 1821 em Cartagena e no Brasili56. Extingue-se o Monstrum Horribilem mas infelizmente, como mentalidades não se mudam decreto, até hoje persiste na América Latina o espectro inquisitorial, não apenas na ideologia moralista e intolerante, como na própria composição das elites locais, cujas tradicionais descendem diretamente dos terríveis Familiares e Comissários do Santo Ofício. ${ }^{57}$ (MOTT, 2017, p. 10)

Voltamos a questão da desobediência epistêmica do Mignolo ao defender que "formas que não são descoloniais, significam permanecer na razão imperial; ou seja, dentro da política imperial de identidades." (MIGNOLO, 2008, p. 290). E no caso podemos afirmar que a descriminalização da sodomia quando deixou de constar nos Códigos Penais do século XIX não significou um gesto decolonial. O primeiro Código Penal do Império brasileiro de 1830, inspirado nos ideais da Revolução Francesa e nos Códigos Napoleônico de 1810, deu origem ao crime de ofensa a moral e aos bons costumes (TREVISAN, 2018), fazendo surgir a figura do pederasta que, segundo Mott (1992, p. 10) "foram chantageados, encarcerados e torturados pelos agentes da nova ordem policial." Acrescenta ainda que "Suicídio, clandestinidade total, baixa estima, marginalidade, assassinatos, passaram a ser o pão de cada dia de milhares de uranistas latino-americanos, rechaçados dentro de suas próprias famílias, humilhados nas ruas, barrados no acesso ao trabalho." (TREVISAN, 2018). Portanto, dentro da política imperial de identidades. 


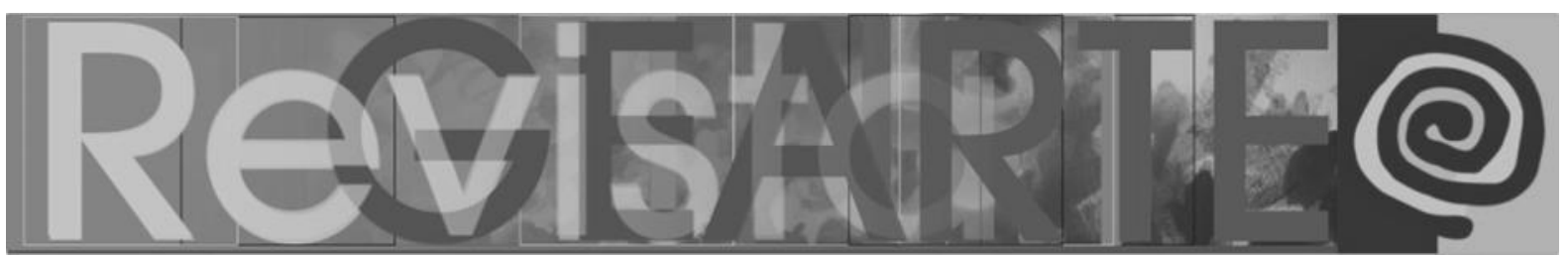

Nem sodomitas, nem pederastas! Entre o Código Penal Imperial e o primeiro Código Penal Republicano de 1890 aparece, em 1869, pela primeira vez na Europa a expressão homossexual.

A partir do final do século XIX observamos na pintura e na fotografia a representação do desejo no nu masculino como as fotografias do fotógrafo alemão, Wilhelm Von Gloeden (1856-1931), que passou a fotografar jovens rapazes da cidade de Taormina - Itália (Figuras 4 e 5), as pinturas e fotografias (Figuras 6 e 7) do pintor, escultor, fotógrafo e professor de arte estadunidense Thomas Cowperthwait Eakins (1844-1916) e do pintor finlandês (Figuras 8 e 9) Knut Magnus Enckell (1870-1925).

Figura 4 - Wilhelm von Gloeden. Fotografia

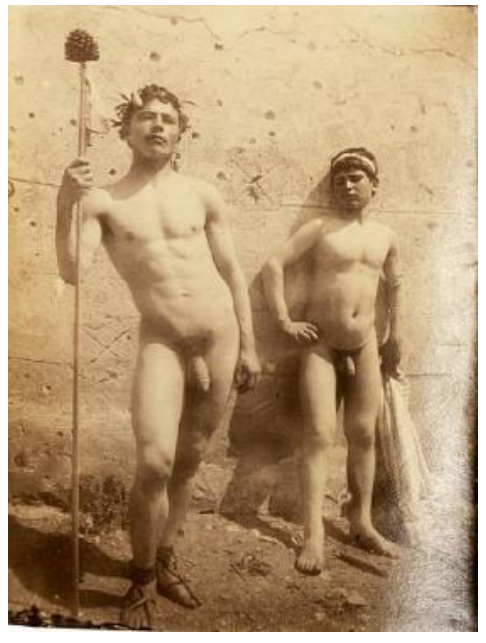

Fonte: Commons. Wikimedia. ${ }^{14}$
Figura 5 - Wilhelm von Gloeden. Fotografia

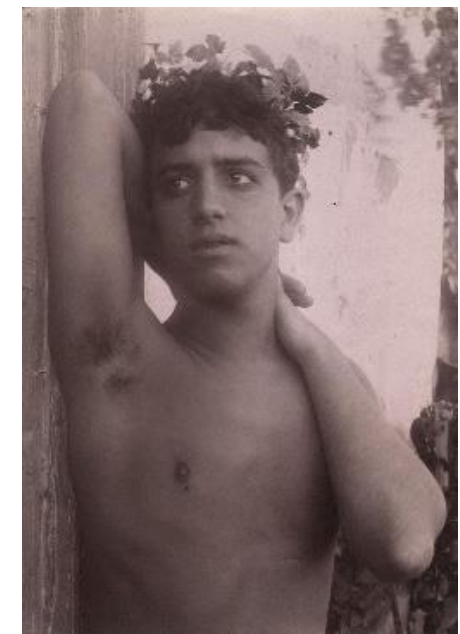

Fonte: worthpoint/worthopedia. ${ }^{15}$

14 Disponível em: <https://commons.wikimedia.org/wiki/File:Gloeden,_Wilhelm_von_(1856-1931)__n._0237_B_recto.jpg>. Acesso em: 15 nov. 2018.

15 Disponível em: <https://www.worthpoint.com/worthopedia/baron-wilhelm-von-gloeden-original184 8584713> Acesso em: 15 nov. 2018.

COSTA, Fábio José Rodrigues da. Ensino/Aprendizagem das Artes Visuais na 


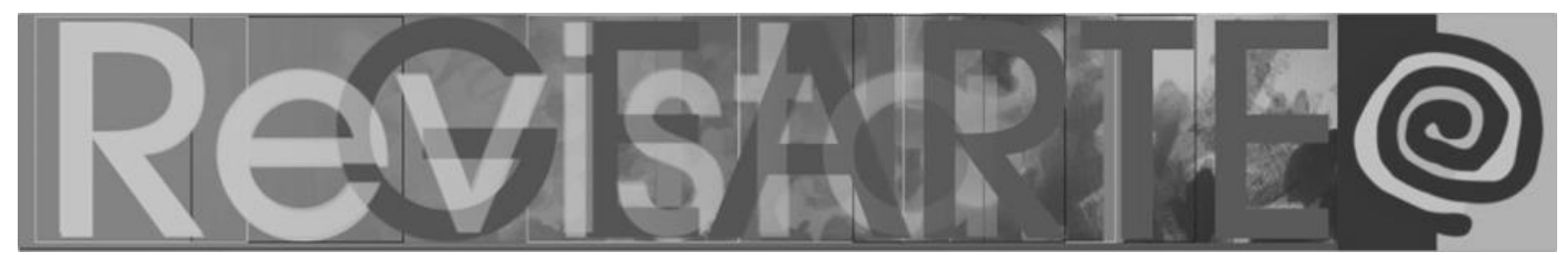

Figura 6 - Thomas Eakins, Bill Duckett Nude

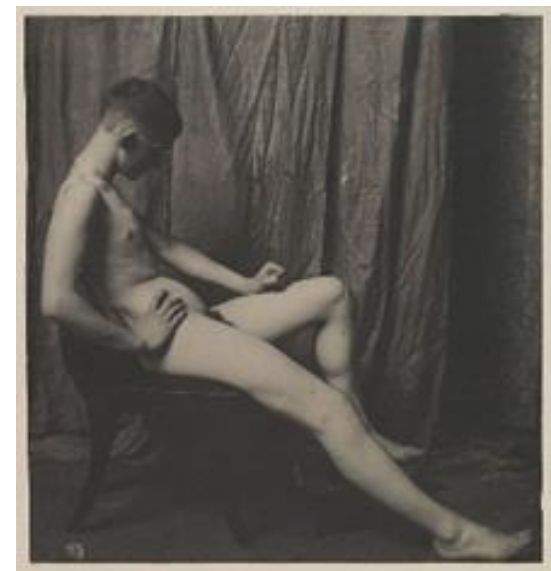

Fonte: wikipedia.org. ${ }^{16}$

Figura 7 - Thomas Eakins, The swimming hole, 1883

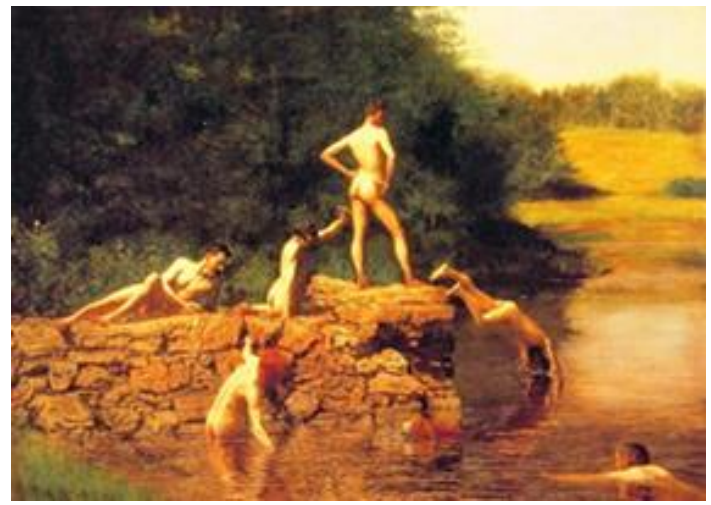

Fonte: wikipedia.org. ${ }^{17}$

16 Disponível em: <https://en.wikipedia.org/wiki/Thomas Eakins\#/media/File:Bill Duckett Nude at the Art Students\%E2\%80\%99 League of Philadelphia.jpg> Acesso em: 15 nov. 2018

17 Disponível em: <https://en.wikipedia.org/wiki/Thomas_Eakins\#/media/File:Swimming_hole.jpg> Acesso em: 15 nov. 2018

COSTA, Fábio José Rodrigues da. Ensino/Aprendizagem das Artes Visuais na

América Latina: colonialidade cultural e emocional aliada a questões LGBT.

Revista GEARTE, Porto Alegre, v. 6, n. 2, p. 197-246, maio/ago. 2019.

Disponível em: http://seer.ufrgs.br/gearte 


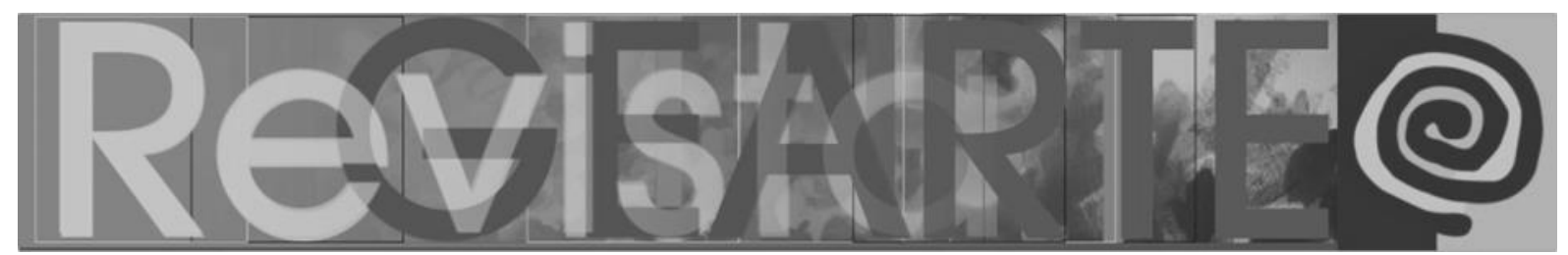

Figura 8 - Knut Magnus Enckell, The raising, 1894

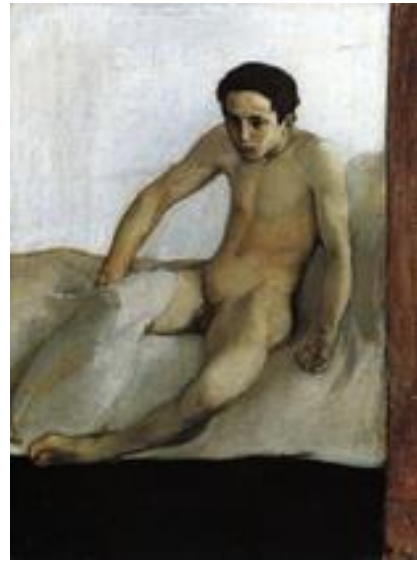

Fonte: wikipedia.org. ${ }^{18}$

Figura 9 - Knut Magnus Enckell, Fauno, 1914

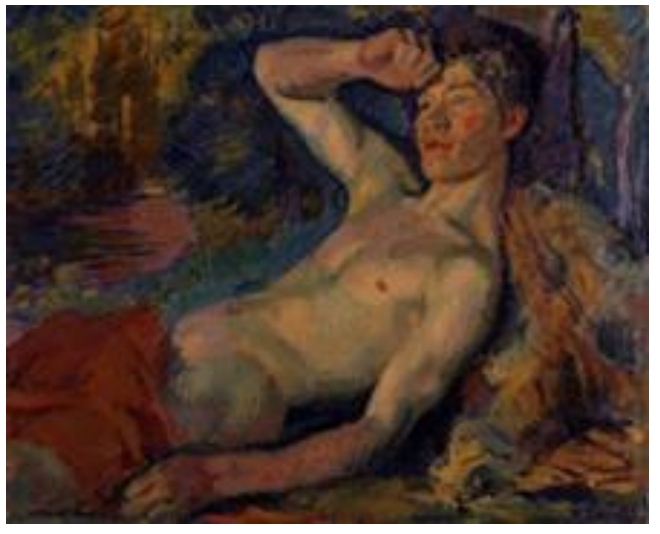

Fonte: wikipedia.org. ${ }^{19}$

Antes do aparecimento da expressão Homossexual foi cunhada a expressão "uranista" pelo alemão Karl-Heinrich Ulrichs (1825-1995) que, segundo Júlio de Assis Simões, em seu livro Do movimento homossexual ao LGBT, publicado em 2009, o jurista "adotava o termo "uranista" para se referir às pessoas que sentiam atração por outras do mesmo sexo (sendo ele próprio uma dessas pessoas)". (SIMÕES, 2009, p. 38). Para Ulrichs os uranistas seriam um "terceiro sexo". O termo ou expressão uranista passou a ser usada e em 1869 pelo jornalista húngaro Karl-Maria Benkert

18 Disponível em: < https://pt.wikipedia.org/wiki/Magnus_Enckell\#/media/File:Enckell,_Magnus_(18701925)_-_1894_-_The_raising.jpg >. Acesso em: 15 nov. 2018.

19 Disponível em:<https://pt.wikipedia.org/wiki/Magnus_Enckell\#/media/File:Enckell,_Magnus_(18701925)_-_1914_-_Fauno.jpg>. Acesso em: 15 nov. 2018. 


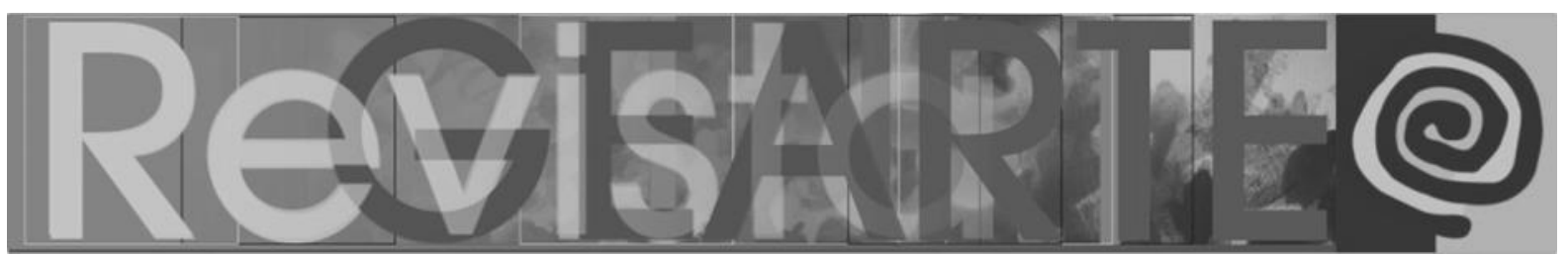

(que mudou seu nome para Károli Maria Kertbeny) contrário a criminalização da sodomia masculina pela lei prussiana, lançou folhetos usando o termo ou expressão Homossexual. (SIMÕES, 2009).

O primeiro gesto de resistência e desobediência epistêmica à criminalização da homossexualidade ocorreu em 1869 quando Benkert escreve uma carta e envia para o ministro da Justiça "argumentando que o Estado não tem porque meter o nariz nos dormitórios de seus cidadãos" (OKITA, 2007, p. 54).

A carta não foi a única estratégia utilizada para combater o Parágrafo 175 do referido Código Penal, uma vez que, tanto na Alemanha como em outros países europeus foram surgindo críticas à criminalização da homossexualidade, e em 1897 foi fundado um Comitê pelo médico, judeu e homossexual Magnus Hirschfeld com os seguintes objetivos: "Ganhar os corpos legislativos para que apoiassem a petição de abolir o Parágrafo anti-homossexuais 175; Trazer a público a verdade sobre a homossexualidade; Interessar os próprios homossexuais na luta em favor de seus direitos." (OKITA, p. 55). "Na sua campanha para abolir o artigo 175 e interessar os homossexuais a lutar em favor de seus direitos, o comitê publicou vários livros e panfletos, além do Anuário para Tipos Sexuais Intermediários." (FRY; MACRAE, 1984, p. 86-87)

O ativismo e o trabalho do Comitê criado por Hirschfeld se manteve na luta contra a anti-homossexualidade chegando em 1919 a fundar em Berlim ${ }^{20}$ o Instituto de Ciência Sexual, além de organizar o Primeiro Congresso Internacional para a Reforma Sexual. As atividades do Comitê foram paralisadas em 1933 pelos nazistas que passaram a aplicar o artigo 175 e deram início ao projeto de extermínio dos homossexuais. Para que possamos ter uma ideia dos efeitos com a aplicação do artigo, em 1933 foram condenadas 835 pessoas, em 1934 chegou a 948, em 1936 o número aumentou para 5.321 condenadas e a partir de 1939 são enviadas aos

20 Até 1920 a cidade de Berlim era considerada a mais tolerante das cidades europeias para a população LGBT no mundo. 


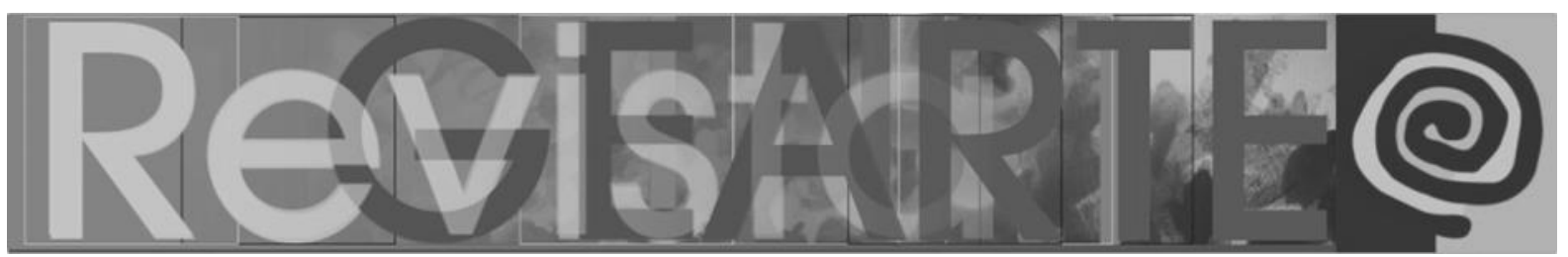

campos de concentração 24.450 pessoas. Estima-se que até o final do Terceiro Reich em 1945, aproximadamente 100 mil homens foram acusados de homossexuais pela polícia ("lista rosa") e desses mais de 50 mil foram oficialmente condenados e aproximadamente 15 mil foram enviados para os campos de concentração de Auschwitz, Dachau, Neuengame, Ravensbruek, Sachsenhausen, Natsweiler, BergenBelsen, Fuehlsbuettel, Fosenberg entre outros. Nesses campos eram identificados com o triângulo rosa invertido (Figura 10), submetidos à castração e obrigados a trabalhos os mais repugnantes e mais pesados e ficavam sem comer, o que colaborava ainda mais para acelerar suas mortes. Em alguns desses campos eram assassinados por soldados por puro prazer de matar, além de serem violentados.

Figura 10 - Uniformizados, marcados com distintivos triangulares

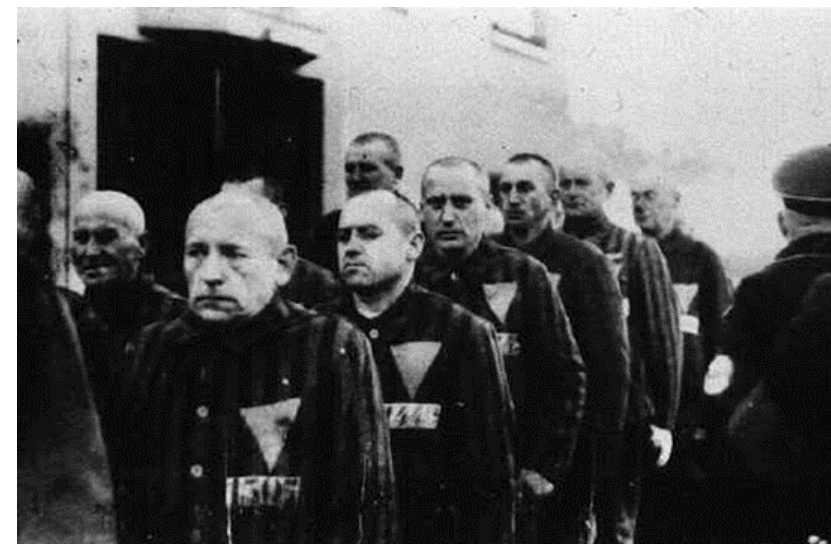

Fonte: Enciclopédia do USHMM. ${ }^{21}$

Em 2014 a companhia de teatro porto-alegrense Teatro ao Quadrado estreou o espetáculo "Os Homens do Triângulo Rosa"22 de autoria do ator Marcelo Ádams, que procura tratar tanto dos horrores como do amor entre homens nos campos de concentração nazista. Outro projeto que nos aproxima das atrocidades do Nazismo e como a população LGBT foi brutalmente perseguida é a iniciativa da artista brasileira, Marina Amaral (MG), que inicia em 2016 o Face of Auschwitz, que consiste em colorir

21 Disponível em: <https://encyclopedia.ushmm.org/content/pt-br/photo/prisoners-in-the-sachs enhausen-camp>. Acesso em: 15 nov. 2018.

22 Ver: <http://www.alagoasboreal.com.br/noticia/5b5b4aa477b5b4529a6f8b3f/os-homens-dotriangulo-rosa-aborda-o-drama-de-homossexuais-no-campo-de-concentracao-nazista>. Acesso em: 15 nov. 2018. 


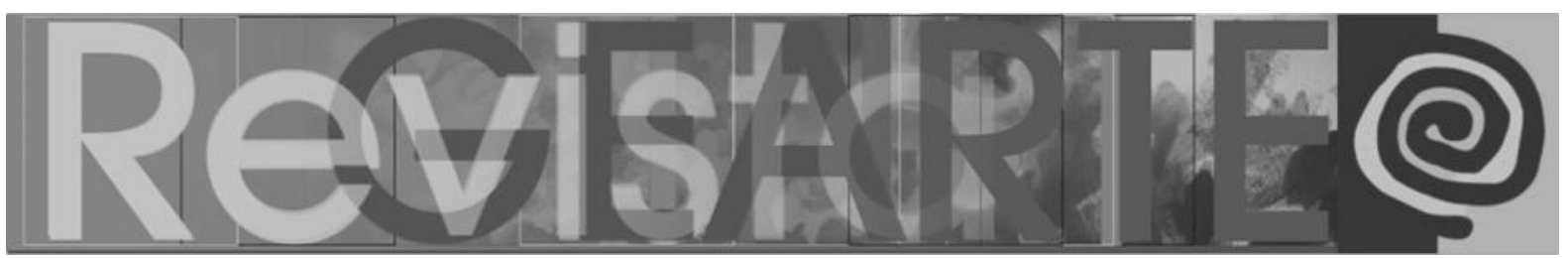

fotografias do campo de concentração nazista. A partir dessa iniciativa podemos compreender melhor o uso da cor pelos nazistas para identificar seus inimigos. ${ }^{23}$

A desobediência epistêmica foi vivida nos campos de concentração durante a Segunda Guerra Mundial, uma vez que, todos os prisioneiros desenvolviam estratégias de sobrevivência e de resistência à crueldade imposta pelo projeto imperial de identidades, como destaca Mignolo (2008):

\begin{abstract}
Infelizmente, nem todos os assassinatos massivos foram registrados com o mesmo valor e a mesma visibilidade. Os critérios não mencionados para o valor das vidas humanas são um óbvio sinal (de uma interpretação descolonial) de política escondida de identidade imperial: quer dizer, o valor de vidas humanas a qual pertence a vida do enunciador, se torna uma vara de medida para avaliar outras vidas humanas que não têm opção intelectual e poder institucional para contar a história e classificar os eventos de acordo com uma classificação de vidas humanas: ou seja, de acordo com uma classificação racista. ${ }^{6}$ (MIGNOLO, 2008, p. 294)
\end{abstract}

No prefácio ao livro Triângulo rosa: um homossexual no campo de concentração nazista (SCHWAB; BRAZDA, 2011), Marie-José Chombart de Luwe Presidente da Fundação pela Memória da Deportação - destaca que a biografia de Rudolf Brazda "se inscreve na pedagogia da memória" (SCHWAB; BRAZDA, 2011, p. 9).

Todas e todos devemos passar pela pedagogia da memória para compreendermos no presente que:

A perseguição aos homossexuais pelo regime nacional-socialista é uma chave de acesso à análise crítica do presente e das normas comportamentais que o caracterizam. Ela não é, nem de longe, a única, e aqui pensamos naturalmente em todos os tipos de "rejeição" cultural, "racial" ou física. (LAUWE in SCHWAB, 2011, p. 10)

Em 2008 a Alemanha reconhece que o holocausto também vitimou as homossexualidades com a inauguração do monumento "O amor que não ousa dizer

23 Ver: <https://facesofauschwitz.com/>. Acesso em: 15 nov. 2018.

COSTA, Fábio José Rodrigues da. Ensino/Aprendizagem das Artes Visuais na 


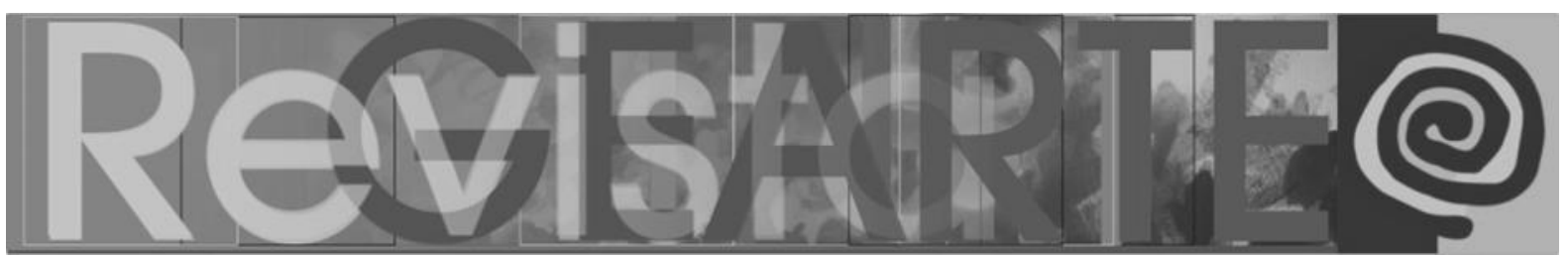

o nome" (Figura 11). O monumento foi aprovado pelo Parlamento Alemão e encomendado aos artistas Ingar Dragset e Michael Elmgreen.

Figura 11 - Memorial $O$ amor que não ousa dizer o nome, Berlim, 2008

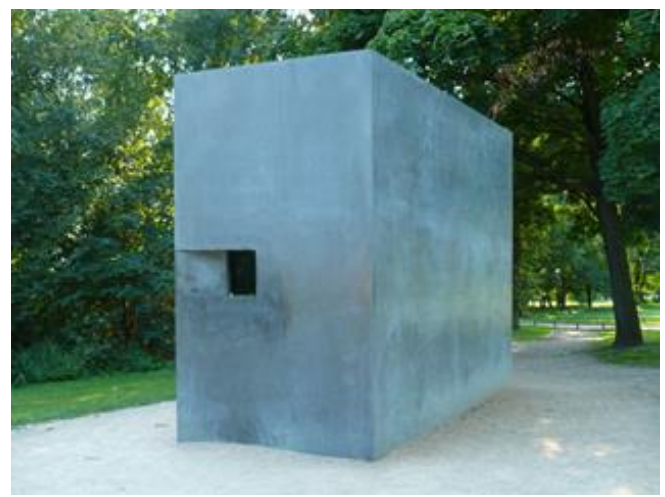

Fonte: Página do DW. ${ }^{24}$

Embora a Alemanha tenha reconhecido o holocausto homossexual e prestado homenagem às vítimas, o preconceito e à LGBTfobia, assim como a criminalização a população LGBT, foi mantida e assumida por muitos países. Por esta razão a luta dessa população para acabar definitivamente com esta opressão continuou gerando manifestações frequentes em diversos países ao longo dos anos de 1970 como a marcha pelo Dia da Libertação Gay, nos Estados Unidos (Figura 12), a marcha de Gays e Lésbicas pelas ruas de Montreal, no Canadá, em 1976 (Figura 13), a marcha do Orgulho Homossexual do México, em 1979 (Figura 14) e a marcha do Orgulho Gay de Madrid, em 1978 (Figura 15) todas exigindo a descriminalização da população LGBT e a garantia de direitos. Ao longo da década de 1970 o movimento LGBT recebeu o apoio de "intelectuais, espalhados em algumas instituições internacionais, mostram sua afinidade com o movimento, publicam ensaios em jornais e revistas e revelam sua estreita ligação com os grupos militantes." (LOURO, 2001 p. 543).

24 Disponível em: <https://www.dw.com/pt-br/homossexuais-v\%C3\%ADtimas-do-nazismo-ganhammemorial-em-berlim/a-3362743>. Acesso em: 15 nov. 2018. 


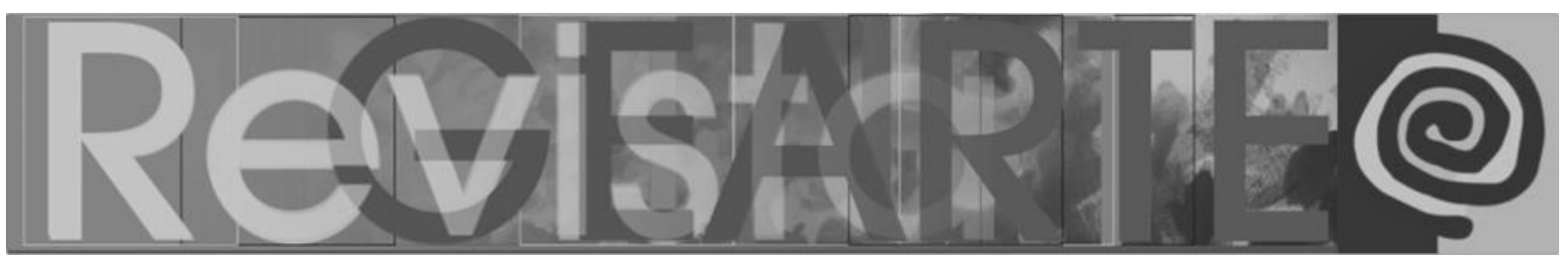

Figura 12 - historical-pride-parade-photos-photography

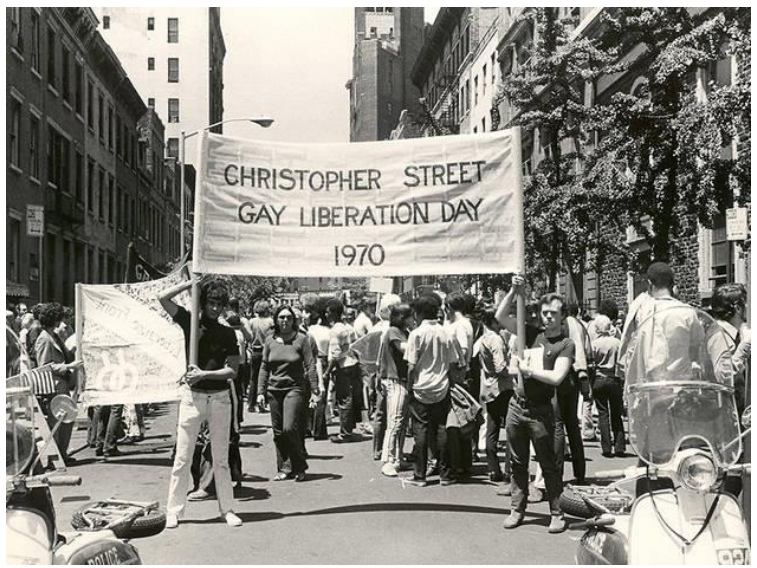

Fonte: Página do TimeOut. ${ }^{25}$

Figura 13 - Gays-and-lesbians-marching-through-Montreals-streets-during-the-June-19-1976Comite

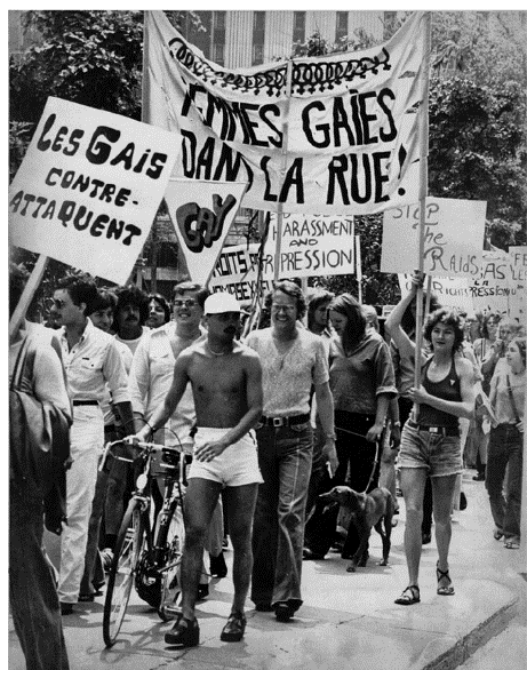

Fonte: Página do researchgate. ${ }^{26}$

25 Disponível em: <https://www.timeout.com/newyork/art/historical-pride-parade-photosphotography>. Acesso em: 15 nov. 2018.

26 Disponível em: <https://www.researchgate.net/figure/Gays-and-lesbians-marching-throughMontreals-streets-during-the-June-19-1976-Comite_fig1_273468368>. Acesso em: 15 nov. 2018.

COSTA, Fábio José Rodrigues da. Ensino/Aprendizagem das Artes Visuais na 


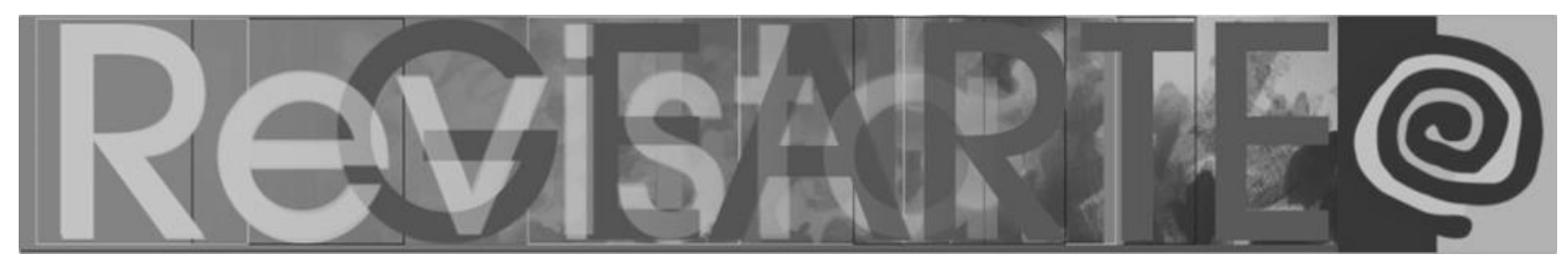

Figura 14 - Cartaz da 2ª Marcha del Orgullo Homosexual, México, 1979.

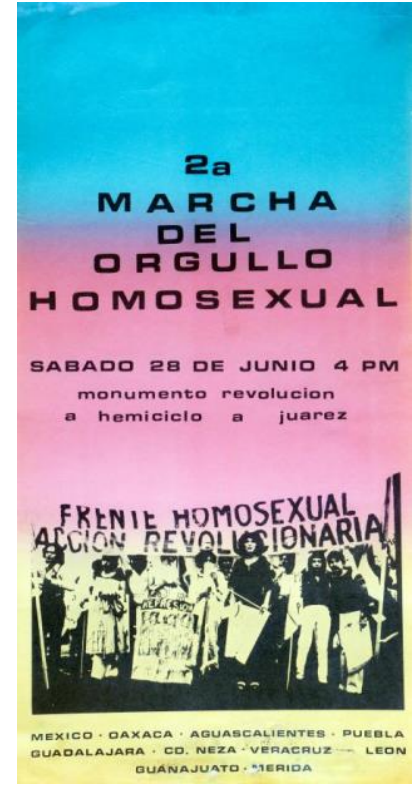

Fonte: El Universal. ${ }^{27}$

Figura 15 — Marcha del Primer Orgullo Gay de Madrid, 1978.

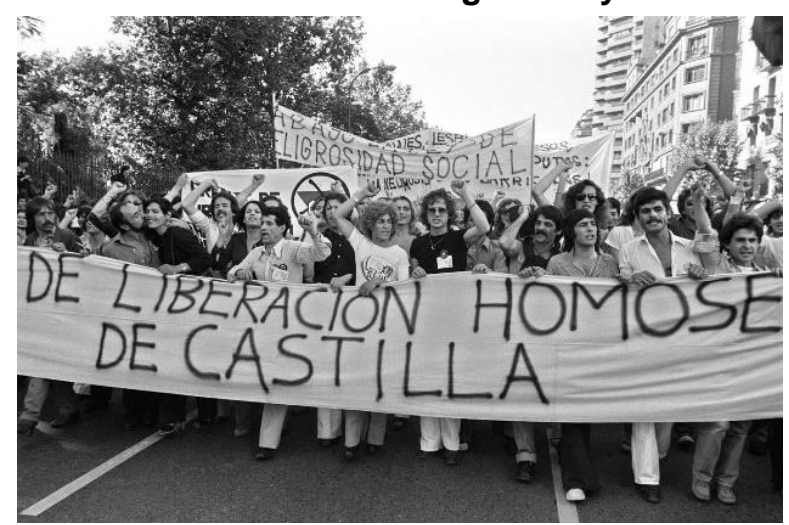

Fonte: $\mathrm{ABC} .28$

No Brasil a construção do movimento LGBT enfrentará inicialmente a repressão advinda da Ditatura Militar, iniciada em 1964. Antes do Brasil ser prisioneiro de seus próprios militares, considero importante destacar que o artista, arquiteto, escritor e performer Flávio de Carvalho (1899-1973), lança New Look - Experiência № 3

27 Disponível em: <https://www.eluniversal.com.mx/colaboracion/mochilazo-en-el-tiempo/nacion/sociedad/ 40-anos-de-las-marchas-gay>. Acesso em: 18 nov. 2018.

28 Disponível em: <https://www.abc.es/espana/madrid/abci-marcha-para-historia-anos-30107398116020180630104324_galeria.html>. Acesso em: 18 nov. 2018. 


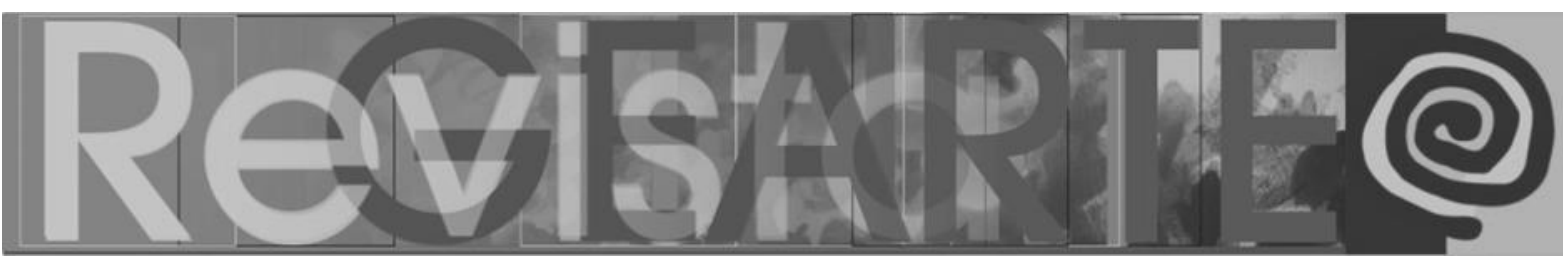

(1956) ${ }^{29}$ e sai pelas ruas de São Paulo vestindo uma saia, passando a ser considerado o pioneiro a colocar em discussão a ortodoxia de gênero em nosso país. O "new look" era composto por saia cor-de-rosa plissada (acima dos joelhos), camisa verde, meia arrastão e sandália de couro cru. Pesquisadores consideram que a performance de Flávio de Carvalho só foi possível porque o Brasil estava livre da ditadura militar que terá lugar a partir dos anos de 1964. Não significa dizer que a população LGBT estivesse livre da opressão, apenas indica que o estado democrático de direitos estava em construção.

Para Lord e Meyer (2013), os anos 50 são geralmente considerados a década mais politicamente conservadora e expressamente homofóbica do século XX. As repercussões de ser identificado como um homossexual na metade do século significavam humilhação social, punição criminal, acusações de doença mental e possível perda de emprego e custódia de crianças. Além de também estarem associadas ao medo do comunismo e das homossexualidades provocando medidas severamente repressivas como: investigações legislativas, listas e prisões criminais, bem como medidas decisivas para resistir a essas medidas.

Diferentemente do movimento de libertação homossexual que ocorria nos Estados Unidos, países da América Latina entram em processos de ditadura militar entre os anos de 1960/70. A ditadura na América Latina não pode ser dissociada das tensões criadas logo após à Segunda Guerra Mundial e o surgimento dos Blocos Comunistas (liderado pela União Soviética) e o Capitalista (liderado pelos Estados Unidos) e o aparecimento da conhecida Guerra Fria.

O medo dos Estados Unidos de uma expansão dos comunistas para a América Latina ficou mais potencializado quando ocorre a Revolução Cubana em 1959, liderada por Fidel Castro. As estratégias para frear possível expansão veio com investimentos e apoio às ditaduras militares à exemplo da Argentina (1966-1973), do Chile (1973-1990), do Brasil (1964-1985), do Uruguai (1973-1985), da Guatemala

29 Ver: <http://www.bienal.org.br/post/368>. Acesso em: 18 nov. 2018. 


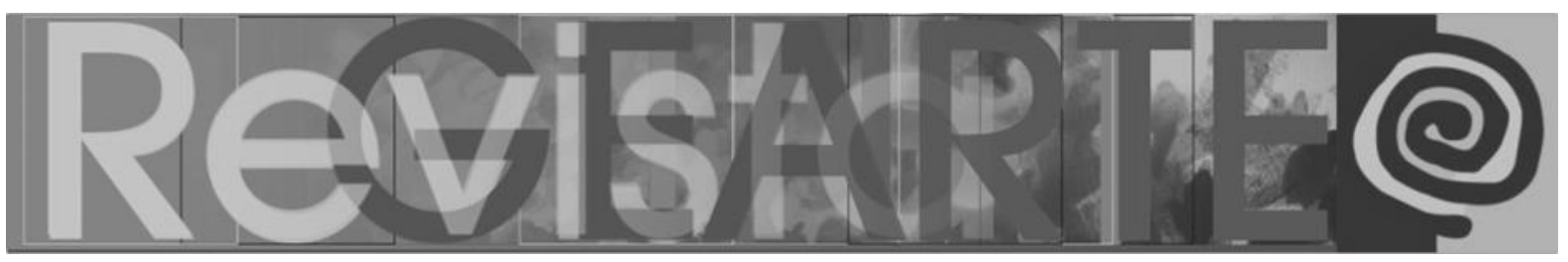

(1954-1996), do Paraguai (1954-1989), da Bolívia (1971-1985), do Peru (1968-1980) e da Nicarágua (1976-1985).

Para o historiador James Green, em entrevista para o também historiador José Gatti, a construção do movimento homossexual no Brasil foi freada pela ditadura militar.

Eu tenho certeza absoluta, pelas mobilizações sociais e as transformações culturais e sociais dos anos 60 a nível mundial, que se o governo Costa e Silva e o governo Médici não estivessem no poder, se não tivesse havido a ditadura militar no Brasil, o movimento gay e lésbico aqui teria surgido já em 1970, num primeiro momento. Porque existia toda uma subcultura gay em formação e uma contracultura brotando que já começavam a questionar os papeis rígidos de masculinidade e feminilidade. Caetano Veloso, os Dzi Croquetes, Ney Matogrosso expressavam uma transformação cultural acontecendo no Brasil. Contudo, no começo dos anos 70 essas mudanças culturais e sociais não podiam manifestar-se politicamente de forma mais explícita, ou seja, não havia as condições necessárias para os gays e as lésbicas brasileiras se organizar num movimento político para enfrentar o preconceito contra a homossexualidade no Brasil. (In: GATTI, 2000, p. 541)

É nesse contexto de ditaduras que artistas, desobedientes epistêmicos, como Carlos Leppe (1952-2015), desafiam a ordem vigente e em 1975 expõe na galeria Módulo y Forma em Santiago do Chile três fotografias presas com cabides de madeira e impressas em papel fotográfico em tamanho grande ${ }^{30}$. As imagens representam o próprio Leppe vestido com roupa feminina igual a de uma extravagante cantora de ópera. Outro artista chileno a desafiar a ditadura é Juan Dávila (1946) que em seu trabalho questiona identidades culturais, sexuais e sociais ${ }^{31}$, resultando em um corpo rico, complexo e provocativo de trabalho. O trabalho de Dávila foi moldado pela agitação política durante a ditadura de Pinochet, no Chile, na década de 1970, transmitindo a violência e a agitação psicológica vivenciadas por seus cidadãos.

30 Ver: <http://artishockrevista.com/2016/07/26/cuerpo-deen-obra-reconstituyendo-leppe/ >. Acesso em: 16 nov. 2018.

31 Ver: <https:/www.roslynoxley9.com.au/artists/47/Juan_Davila/917/50541>e <https://www.roslynoxley9.com.au/artists/47/Juan_Davila/917/50546/>. Acesso em: 16 nov. 2018. 


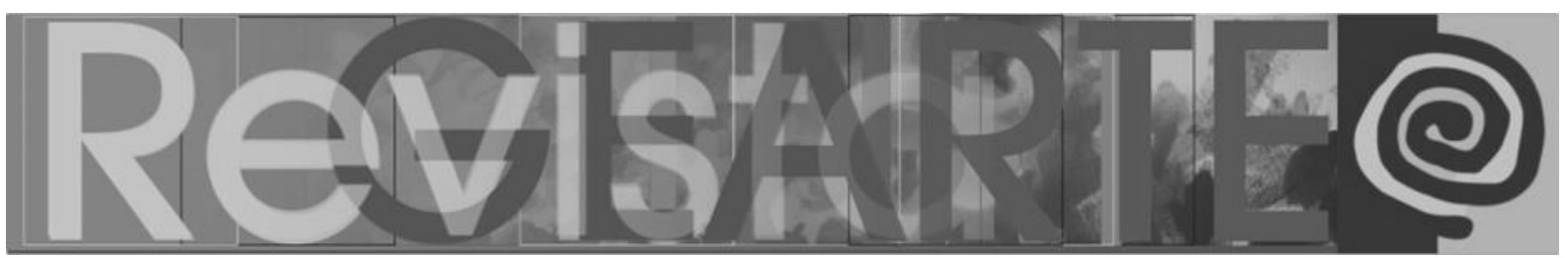

A desobediência epistêmica tomava conta da América Latina e, no Brasil de 1970, em plena ditadura militar, surge no Rio de Janeiro o coletivo ou grupo teatral Dzi Croquettes (1972). O caráter irreverente do coletivo demonstrava seu projeto antinormativo ${ }^{32}$ no qual "radicalizavam as confusões de gênero, misturando barbas e cílios postiços, sutiãs e peitos peludos, meiões de futebol e saltos altos." (SIMÕES, 2009, p. 76). Para Odailso Sinvaldo Berté e Gustavo de Oliveira Duarte (2018):

\begin{abstract}
A força político-estética do trabalho dos Dzi alavancou, de certa forma, variadas formas de expressão e visibilidade das identidades homossexuais. Parte da liberdade de expressão hoje conquistada vem dessas e outras formas de manifestação que encamparam as articulações políticas e identitárias afloradas em meio às tensões políticas vividas naquela época. (BERTÉ; DUARTE, 2018, p. 493)
\end{abstract}

Ainda no Brasil surge o jornal Lampião da Esquina em 1978, com o objetivo de "destruir a imagem-padrão que se tem do homossexual, segundo a qual ele é um ser que vive nas sombras, que prefere a noite, que encara sua preferência sexual como uma espécie de maldição" (FOLHA, 18/08/2016). O jornal se tornou a referência para o movimento LGBT e durou de 1978 a 1981 (Figuras 16, 17, 18). Embora a produção e veiculação do jornal tenha durado pouco, podemos dizer que o mesmo foi uma das mais expressivas desobediências epistêmicas vivenciadas ainda na ditadura militar no Brasil.

Figura 16 - Capa do Lampião da Esquina, Edição 0, 1978

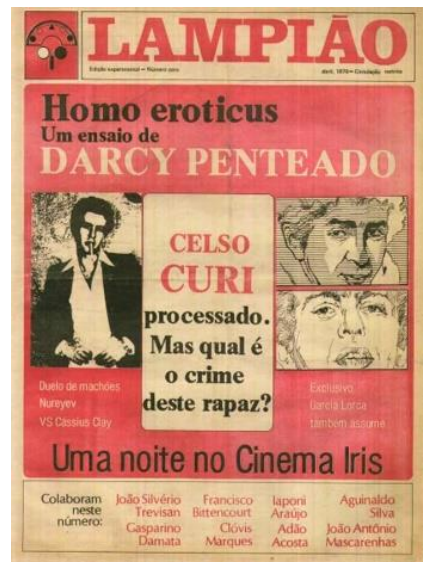

32 Ver: <https://zupi.pixelshow.co/construcao-olhar-nacional/>. Acesso em: 18 nov. 2018. 


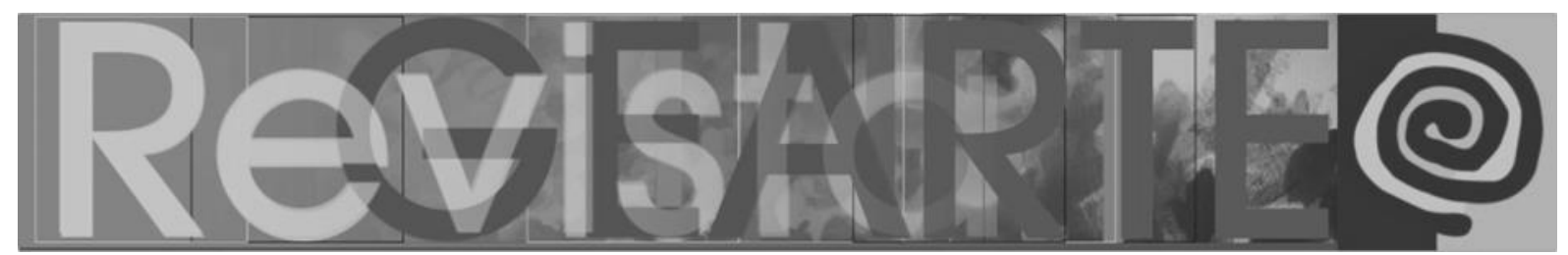

Fonte: Grupo Dignidade. ${ }^{33}$

Figura 17 - Capa do Lampião da Esquina, edição 13, 1979

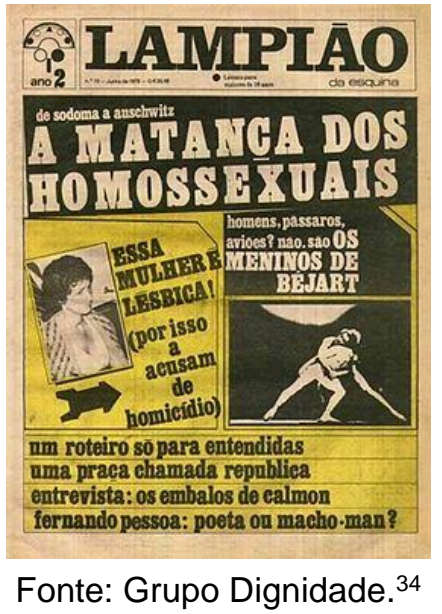

Figura 18 - Capa do Lampião da Esquina, edição 20, 1980

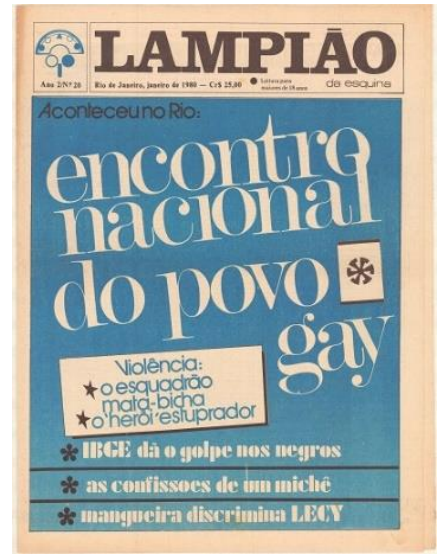

Fonte: Grupo Dignidade. ${ }^{35}$

O número zero do Lampião da Esquina (1978) traz importante ensaio que registra a trajetória e produção de Darcy Penteado (1926-1987) que a descreveu em em um texto crítico sobre a representação do nu masculino e sua relação com o "erótico-homossexual". Assim Penteado se referia a seus desenhos produzidos entre 1948 e 1949. O referido ensaio, intitulado "Eu criei a arte erótico-homossexual no

33 Disponível em: <http://www.grupodignidade.org.br/projetos/lampiao-da-esquina/>. Acesso em: 18 nov. 2018.

34 Disponível em: <http://www.grupodignidade.org.br/projetos/lampiao-da-esquina/>. Acesso em: 18 nov. 2018.

35 Disponível em: <http://www.grupodignidade.org.br/projetos/lampiao-da-esquina/>. Acesso em: 18 nov. 2018. 


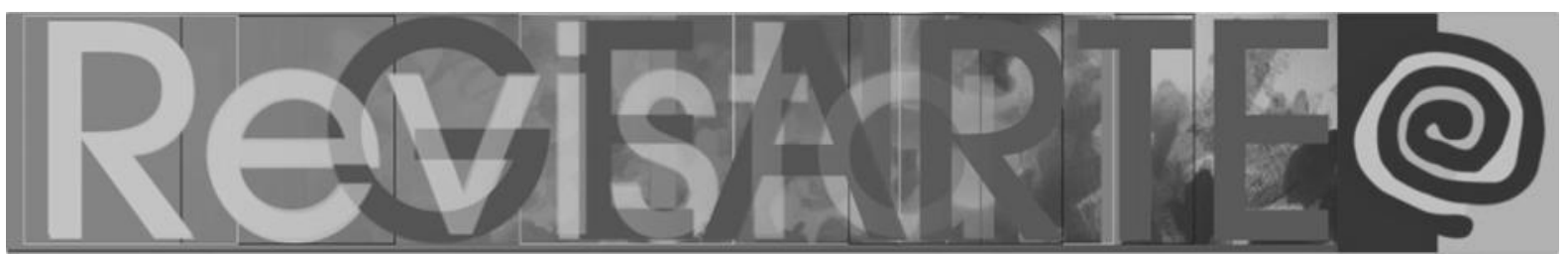

Brasil", é ilustrado com um de seus trabalhos (Figura 19), que extraímos da versão digital do número zero do Jornal o Lampião da Esquina. Já no número 28 do Lampião da Esquina (1980) há outro trabalho erótico-homossexual. ${ }^{36}$

Figura 19 - Darcy Penteado, Lampião da Esquina, edição 0, 1978, e excerto do ensaio
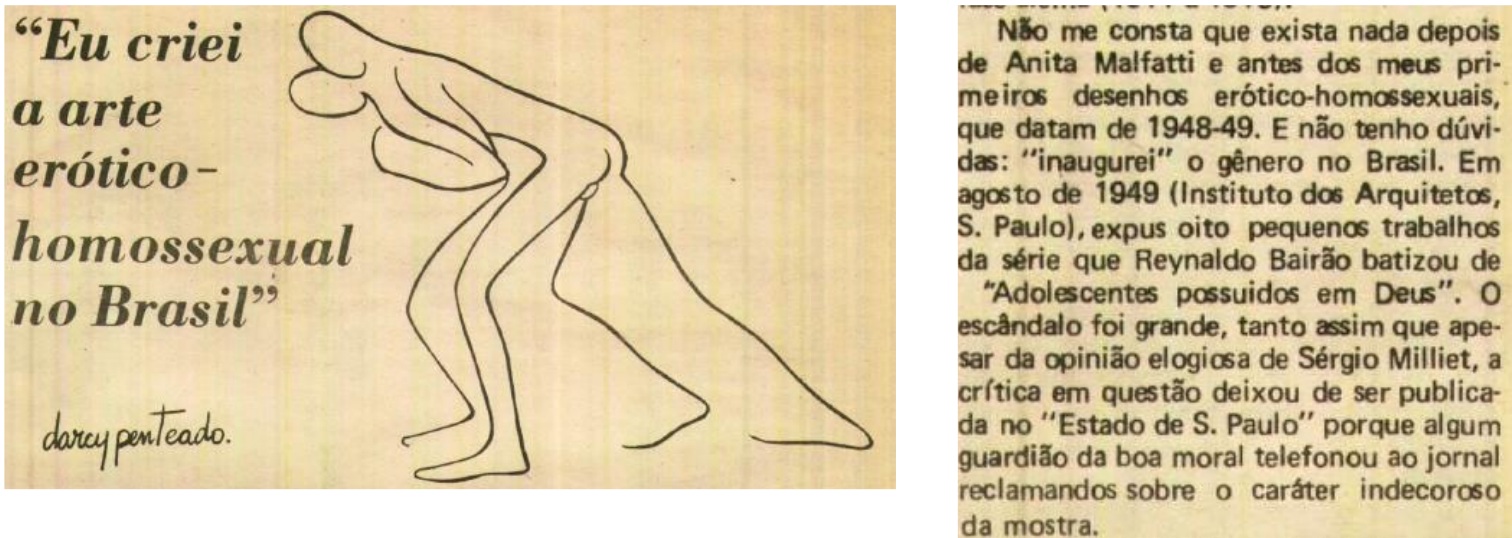

Fonte: Grupo Dignidade. ${ }^{37}$

Outro importante nome das artes visuais foi o Alair Gomes (1921-1992). Alair era carioca e formado em Engenharia e se dedicou ao estudo da matemática, da lógica e da biologia. Sua paixão pela fotografia teve início nos anos 60 passando a fotografar os rapazes que se exercitavam na praia de Ipanema. ${ }^{38}$ Hoje é considerado o precursor da fotografia homoerótica no Brasil ${ }^{39}$.

Para Alexandre Santos (2008),

Foi em 1966 que o artista começou a aventurar-se na fotografia de rapazes na rua, produzindo longas sequências que o tornariam um dos precursores do homoerotismo fotográfico no Brasil. É nessa linha específica de produção que se pode creditar o estreitamento dos vínculos de Gomes com a contemporaneidade artística, mesmo que posteriores ao seu desaparecimento. Embora em diversos momentos de sua carreira ele tenha declarado que, no início, as imagens teriam sido feitas sem nenhuma pretensão artística, elas acabaram por constituir-se o centro de sua obra. $\mathrm{O}$

36 Ver: <http://www.grupodignidade.org.br/projetos/lampiao-da-esquina/>. Acesso em: 18 nov. 2018.

37 Disponível em: <http://www.grupodignidade.org.br/projetos/lampiao-da-esquina/>. Acesso em: 18 nov. 2018.

38 Ver: <https:/rudychic.tumblr.com/post/44735090902/beach-triptych-n\%C2\%BA-25-1985-alair-gomesmuseu-de>. Acesso em: 18 nov. 2018.

39 Ver: <https://www.otempo.com.br/divers\%C3\%A3o/magazine/obra-in\%C3\%A9dita-de-alair-gomes1.828935>. Acesso em: 18 nov. 2018. 


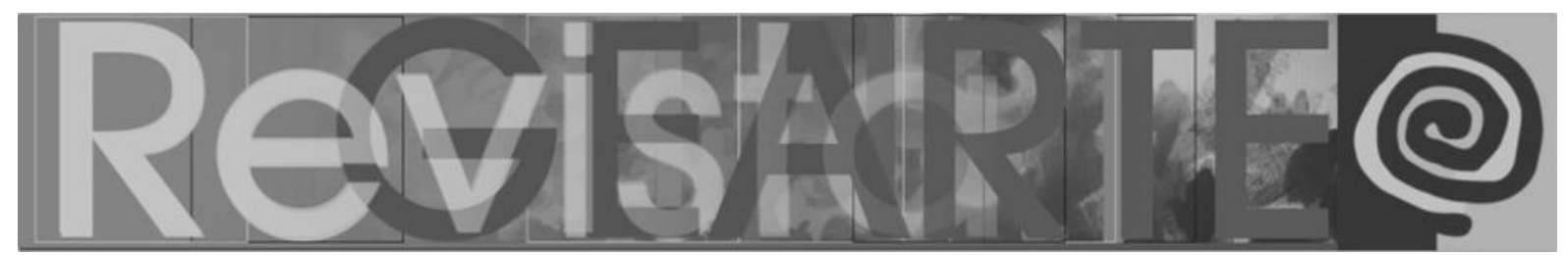

posicionamento esquivo de Alair em relação às suas imagens homoeróticas é talvez fruto do constrangimento de sua época em relação às poéticas de cunho mais pessoal. (SANTOS, 2008, p. 59)

Segundo Santos (2008), a natureza biográfica e autobiográfica de Alair Gomes, encontra-se nos mais de 170 mil negativos deixados pelo artista e compreende o período de 1966 a 1991. No tocante às fotografias de rapazes, Santos destaca:

A vasta coleção de imagens de jovens rapazes feita por Alair é classificada em três grandes categorias, assim identificadas por ele: 1. Beach, que compreende Sonatinas, four feet (Sonatinas a quatro pés), Beach triptychs (Trípticos de praia), Serial composition (Composição seriada) e Friezes (Frisos); 2. Kids (Garotos), composta por Symphony of erotic icons (Sinfonia de ícones eróticos), Diário de Sumidouro e Fragments from opus 3 (Fragmentos do Opus 3), dentro da qual há a série Adoremus (Adoremos); e 3. Finestra (Janela), na qual se encontram as subcategorias $A$ window in rio (Uma janela no rio), The course of the sun (O curso do sol) e The nostory of a driver (A não-história de um chofer). Mesmo "desdenhando" essa produção, é a ela que o artista dedicou maior atenção, como a preparar para a posteridade, de forma visionária, o vislumbre possível de sua obra. (SANTOS, 2008, p. 60)

Para Resende (2016, p. 126), Alair Gomes "construiu em suas fotos um elogio ao amor homoerótico."

Antes mesmo do aparecimento do HIV/AIDS, no México o artista Armando Cristeto (1957) desenvolve uma série fotográfica ${ }^{40}$ através da justaposição de dois negativos na qual um jovem está despido e cobre parcialmente seu rosto e em suas mãos luvas de látex. Na parte inferior da imagem, o homem segura seu pênis com uma camisinha (1978).

Para Aliaga e Cortés, (2014), a prática artística de Armando Cristeto

Se puede leer esta obra como alusiva al temor al contagio asociado a las enfermedades de transmisión sexual, pero no directamente al sida pues precede a la aparición del VIH. Sin embargo, estamos ante uno de los primeros ejemplos de representación del cuerpo masculino desnudo y fuertemente sexualizado en México como atestiguan otras imágenes de la misma serie titulada El condón, algo insólito en México en esos años donde

40 Ver: http://archivosenuso.org/viewer/968> e https://muac.unam.mx/objeto/el-condon>. Acesso em: 18 nov. 2018

COSTA, Fábio José Rodrigues da. Ensino/Aprendizagem das Artes Visuais na 


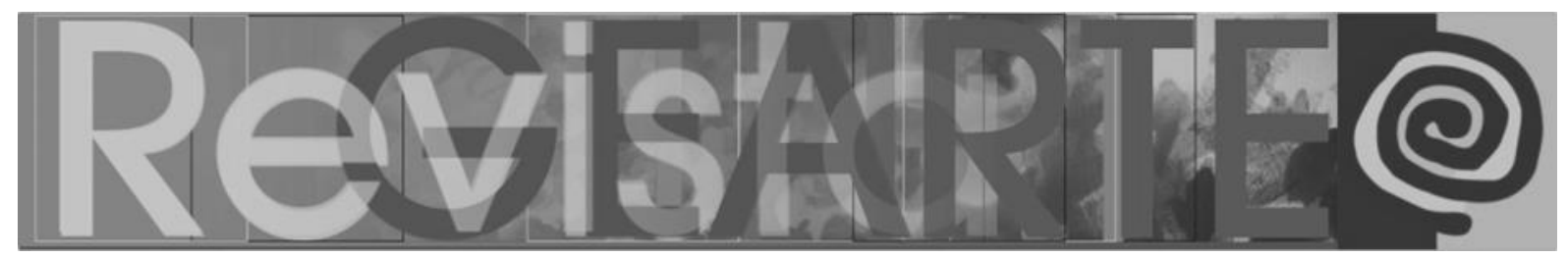

el silencio sepulcral aplastaba la simple mención de la homosexualidad. (ALIAGA; CORTÉS, 2014, p. 68)

O número de pesquisas sobre a sexualidade cresceu na década de 1980, por causa da epidemia de AIDS. A princípio foi atribuída equivocadamente, como uma doença ligada aos homossexuais, o que provocou uma reação imediata, renovando e intensificando a homofobia e a discriminação. "(...) além de viverem com a incerteza permanente em relação à cura da doença, convivem com as reações de medo, de ódio e distanciamento de amigos e familiares quando se descobrem portadores do vírus." (MARQUES FILHO, 2007, p. 32). Para Aliaga e Cortés (2014):

El sida fue una patología convertida en estigma social que transformó las relaciones sexuales entre los individuos durante décadas haciéndolos más frágiles y temerosos, presas del miedo al contagio, pero que ha resultado asimismo un acicate para impulsar la lucha contra la ignorancia y los prejuicios homófobos. (ALIAGA; CORTÉS, 2014, p. 69)

Em 1991, o artista brasileiro Rafael França (1957-1991) nos deixou seu último trabalho Prelúdio de Uma Morte Anunciada (1991). O vídeo foi concluído pouco antes da morte do artista e ao som de La Traviata (interpretação de Bidu Sayão), o corpo do artista toca o do namorado, Geraldo Rivello. Por cima deles, na tela, aparecem nomes de amigos mortos pela AIDS (Figura 20).

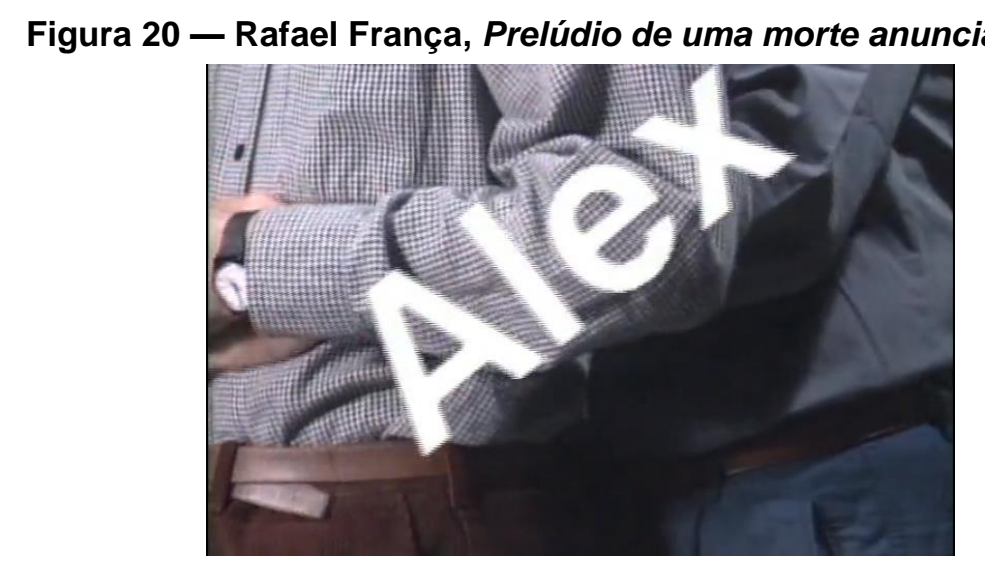

Fonte: Captura de tela do Vídeo. ${ }^{41}$

41 Disponível em: <https://vimeo.com/65248719>. Acesso em: 18 nov. 2018.

COSTA, Fábio José Rodrigues da. Ensino/Aprendizagem das Artes Visuais na 


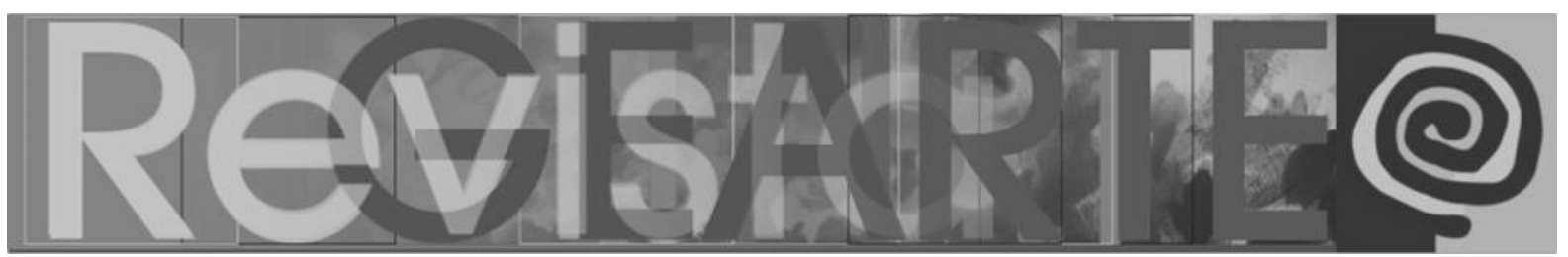

Artistas como o argentino Roberto Jacoby (1944) realiza em 1994 o projeto Yo tengo SIDA (Figura 21), "una acción difundida a través de los diarios Clarín, La Razón y Página 12 consistente en llevar una camiseta con el texto citado en la vía pública y en cualquier otro espacio." (ALIAGA; CORTÉS, 2014, p. 69). Para os autores o artista "trataba de erosionar así el componente demonizador que se asociaba con esta enfermedad que, en el imaginario colectivo mayoritario, era exclusivamente propia de homosexuales, drogadictos y gentes de mal vivir que merecían ser condenados por ello." (ALIAGA; CORTÉS, 2014, p. 69).

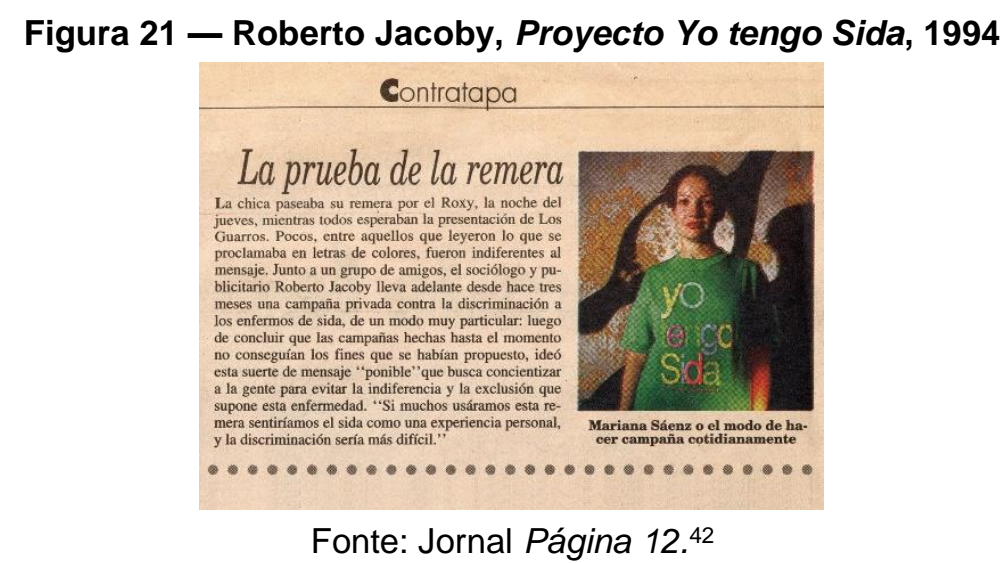

Em 1994, por ocasião das comemorações do 25ํaniversário de Stonewall, o artista chileno Pedro Lemebel (1952-2015), em ato performativo pelas ruas de New York, caminha seminu com o corpo pintado simulando um quadro anatômico com órgãos internos e ossos desenhados levando na cabeça uma coroa de espinhos formada por seringas hipodérmicas. Em suas mãos um cartaz denunciando a presença da AIDS no Chile, ocultada pelas autoridades governamentais de seu país ${ }^{43}$.

No contexto latino-americano, o artista cubano Felix Gonzalez-Torres (19571996) foi o mais significativo na luta pelos direitos dos homossexuais, assim como pelo combate a AIDS. Sua prática artística ultrapassou os limites das galerias, museus

42 Disponível em: http://archivosenuso.org/viewer/968\#. Acesso em: 18 nov. 2018.

43 Ver: https://atlasiv.com/2016/11/25/arder-no-es-desaparecer-sobre-la-muestra-de-pedro-lemebelen-el-museo-de-la-memoria-y-los-derechos-humanos/alacranes-en-marcha-prensa-2/>. Acesso em: 18 nov. 2018. 


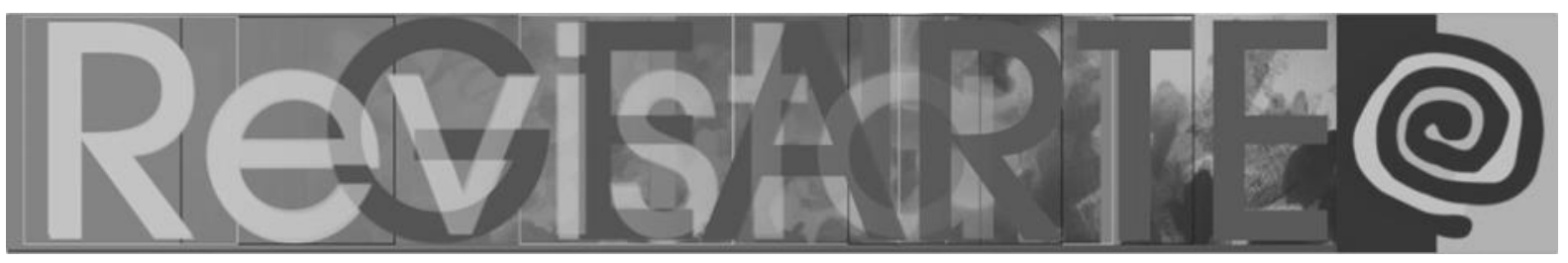

e centros culturais passando a ocupar espaços públicos como ruas e praças utilizando o outdoor como suporte. O primeiro trabalho de Gonzalez-Torres a ocupar o espaço público foi uma instalação (1989) no West Village, em New York, na esquina da Sétima Avenida com a Rua Christopher, acima do Village Cigars e a poucos passos do bar Stonewall ${ }^{44}$.

Para Cortés (2014), essa primeira intervenção urbana de Gonzalez-Torres é

\begin{abstract}
un inventario de fechas ('Coalición para personas con Sida 1985 Hostigamiento policial 1969 Oscar Wilde 1895 Tribunal Supremo 1986 Harvey Milk 1977 Marcha a Washington 1987 Rebelión de Stonewall 1969") en el que se traza un siglo de lucha por la liberación homosexual, pero planteada con un orden arbitrario para evitar un carácter narrativo lineal, ya que para el artista cubano la historia no puede ser entendida como una progresión racional de acontecimientos. (CORTÉS, 2014, p. 125)
\end{abstract}

Segundo Cortés as datas "no tratan de crear una heroica visión del mundo gay, ni tienen un carácter cronológico, más bien son diferentes hechos de características muy distintas que coexisten, como en la memoria, de un modo aleatorio, extraño y un tanto confuso" (CORTÉS, 2014, p. 125). As datas são "fechas fundamentales que Gonzalez-Torres escribe con letras blancas sobre fondo negro, y dejando un gran espacio vacío para que sea el espectador quien reconstruya su significado a partir de su propia memoria personal” (CORTÉS, 2014, p. 125).

Felix Gonzalez-Torres "construiu uma obra que é uma metáfora do cotidiano e uma meditação sobre o amor e a perda do outro em tempos de Aids - doença que afetou diretamente a comunidade homossexual masculina, nos anos 1980 e 1990." (RESENDE, 2016, p. 124). Em 1990, Gonzalez-Torres perde seu marido para a Aids e em 1991 exibe em New York, seu mais conhecido trabalho - Cama, ${ }^{45}$ que, para Cortés (2014),

se puede observar la imagen de una cama deshecha con dos almohadas que guardan claramente la huella de las personas que recientemente la han

44 Ver: http://m.andrearosengallery.com/artists/felix-gonzalez-torres>. Acesso em: 20 nov. 2018.

45 https://gq.globo.com/Colunas/Paulo-Azeco/noticia/2018/06/arte-em-um-mundo-depreconceito.html>. Acesso em: 18 nov. 2018. 


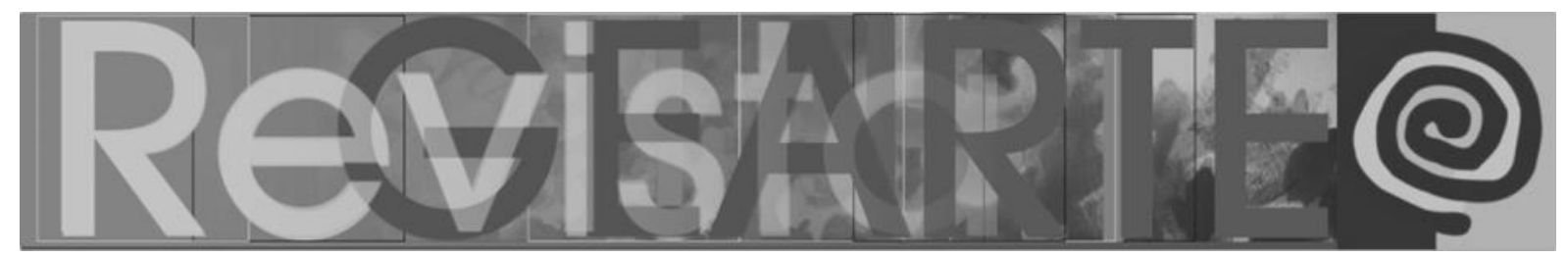

ocupado. Con esta fotografía Felix Gonzalez-Torres llama nuestra atención sobre la calidez y el confort asociado a la cama, al tiempo que muestra una imagen de desposesión y desolación. La privacidad de la habitación está íntimamente relacionada con aquellos que allí duermen, con placeres pasados, con intimidades vividas, con momentos perdidos. (CORTÉS, 2014, p. 126)

Ao longo dos anos nos diferentes países latino-americanos foram surgindo importantes nomes da população LGBT que se tornaram ativistas políticos e artivistas com uma produção visual a qual passou e ainda passa ao largo das salas de aulas quando falamos de ensinar e aprender artes visuais. A ausência de pesquisas que cartografem a rica produção artística nas linguagens das artes visuais desses artistas tem contribuído para a manutenção de um conceito de artes visuais centrado nas "obras" de artistas heterossexuais, brancos, ricos, europeus ou estadunidenses.

\section{Aprender a desaprender - terceira desobediência epistémica: (Re)Existir para combater o fascismo}

Argentina, Bolívia, Canadá, Chile, Colômbia, Equador, El Salvador, Estados Unidos, Honduras, Nicarágua, Peru, Uruguai, Timor Leste, Albânia, Andorra, Bélgica, Croácia, Dinamarca, Eslováquia, Espanha, Finlândia, França, Geórgia, Grécia, Holanda, Hungria, Kosovo, Lituânia, Luxemburgo, Malta, Montenegro, Noruega, Portugal, Reino Unido, San Marino, Servia, Suécia, Suíça, Nova Zelândia, Samoa. (Países que têm leis que punem crimes de ódio motivados por orientação sexual)

Em conexão com o movimento político, cresce, internacionalmente, o número de trabalhadores/as que se assumem como lésbicas, gays, bissexuais, travestis e transexuais na mídia, na imprensa, nas artes e nas universidades. Entre esses/as, há os/as que passam a "fazer da homossexualidade um tópico de suas pesquisas e teorizações". (LOURO, 2001, p. 544). Segundo Marques Filho "através das paradas dia da liberdade (freedom day) - gays, lésbicas, transexuais, travestis, bissexuais ganham visibilidade nunca antes alcançada, aproveitando para celebrar a diversidade 


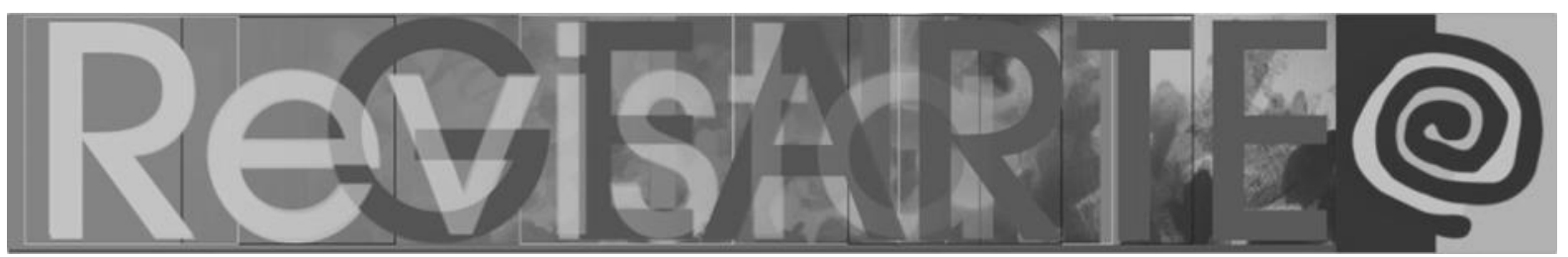

e o amor sem preconceito." (MARQUES FILHO, 2007, p. 84). As paradas são outra estratégia de desobediência epistêmica mantida pela população LGBT no mundo. ${ }^{46}$

A luta do movimento LGBT é, acima de tudo, comprometida com ações que vislumbrem mudanças profundas na sociedade em todos os aspectos no tocante ao desenvolvimento de "um processo cultural e sexual aberto, livre de repressões." (OKITA, 2007, p. 103). Para Simões (2009) "As paradas, como manifestações de visibilidade de massa, marcam a expressão social e política do movimento LGBT dos últimos anos e são, também, um terreno privilegiado para se apreciar o cruzamento das diversas conexões do movimento com o mercado e o Estado" (SIMÕES, 2009, p. 150).

Neste contexto, nas Artes Visuais, artistas realizam trabalhos (do desenho à performance) problematizando questões relativas à população LGBT. Hoje nos deparamos com uma infinidade de imagens produzidas por artistas militantes do movimento e estes trabalhos estão adentrando as principais mostras de artes do mundo como é o caso da Bienal de São Paulo que em sua 29a Edição (2010) abrigou o trabalho da artista Zanele Muholi (África do Sul), com a série Faces and Phases (Faces e Fases) que foram produzidas entre 2006 a 2010.47 Nesta mesma edição participaram os artistas Miguel Angel Rojas (1946, Colômbia), Nan Goldin (1953, Estados Unidos) e José Leonilson (1957-1993).

De acordo com o Catálogo ${ }^{48}$ (p. 242), o trabalho de Muholi

O seu ativismo visual e de gênero constitui uma tentativa de amplificar a voz e o espaço dessas mulheres, uma plataforma identitária muito específica dentro da sociedade contemporânea sul-africana. Atuando à parte aos demais movimentos queer, geralmente coordenados por elementos masculinos, homossexuais, europeus e norte-americanos, esta comunidade

46 Ver foto da $20^{\text {a }}$ edição da Parada do Orgulho LGBT em: http://www.sintratel.org.br/site-joomla1.5/index.php/destaques/1097-sintratel-vai-a-parada-lgbtt-defender-liberdade-e-combater-aviolencia. Acesso em: 20 nov. 2018.

47 Ver: <http://www.walthercollection.com/en/>. Acesso em: 20 nov. 2018.

48 Ver: <http://www.bienal.org.br/publicacoes/2072>. Acesso em: 20 nov.2018.

COSTA, Fábio José Rodrigues da. Ensino/Aprendizagem das Artes Visuais na 


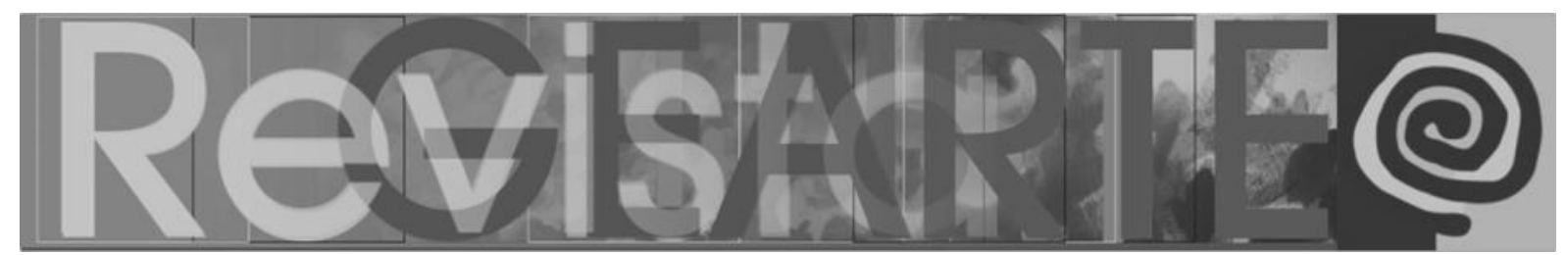

quase invisível é altamente estigmatizada, alvo de preconceito, agressividade, estupro e assassinato.

A 31르 Edição (2014) da Bienal de São Paulo dedicou espaços a artistas como Hudinilson Jr. (1957-2013), com a instalação Zona de tensão anos 1980, organizada por Marcio Harum (Figura 22). Ao filósofo/artista Giuseppe Campuzano (1969-2013), com a instalação Línea de vida/Museo Travesti del Peru (Figura 23), a Sergio Zevallos (Peru, 1962) do coletivo Chaclacayo, a Nahum Zenil (México, 1947), a Pedro Lemebel (1952-2015) e Francisco Casas do coletivo Yeguas del Apocalipsis do Chile, instalação Dios es marica (Figura 24), organizada por Miguel A. López e à Ocaña (Espanha, 1947-1983).

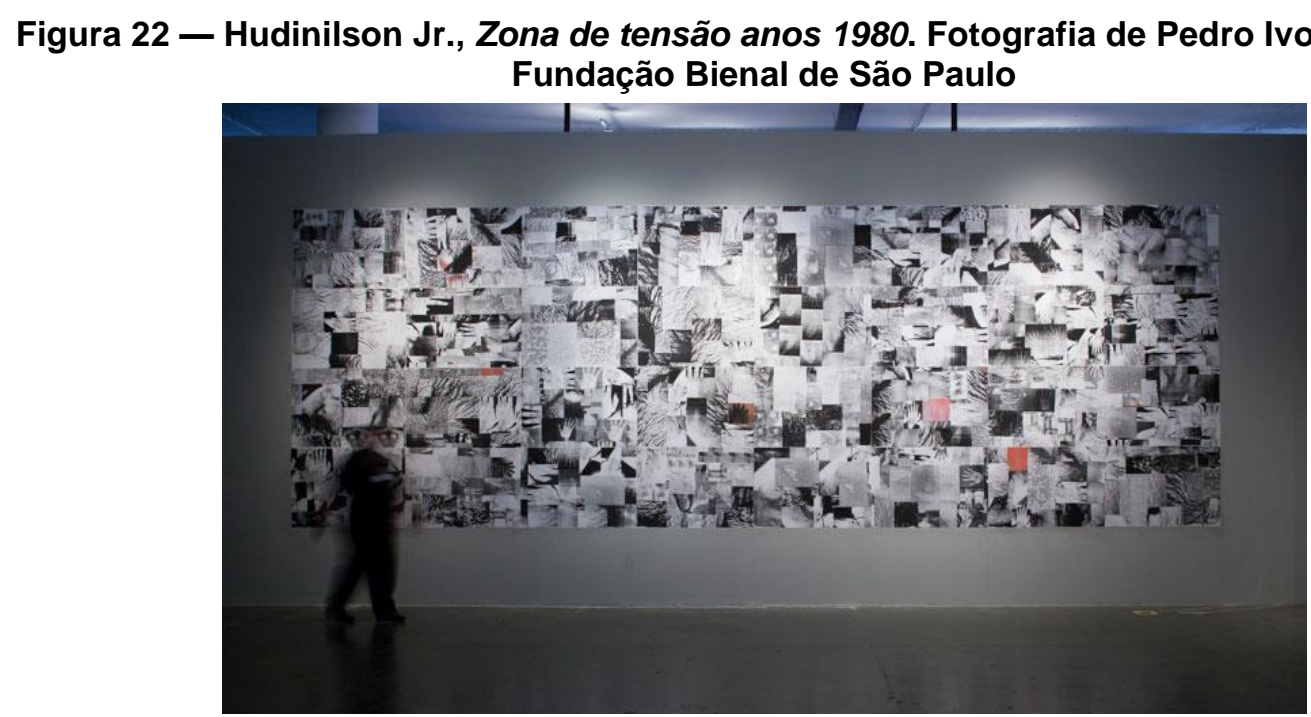

Fonte: Fundação Bienal de São Paulo. ${ }^{49}$

49 Disponível em: <http://www.bienal.org.br/exposicoes/31bienal/fotos/4087>. Acesso em: 20 nov. 2018. 


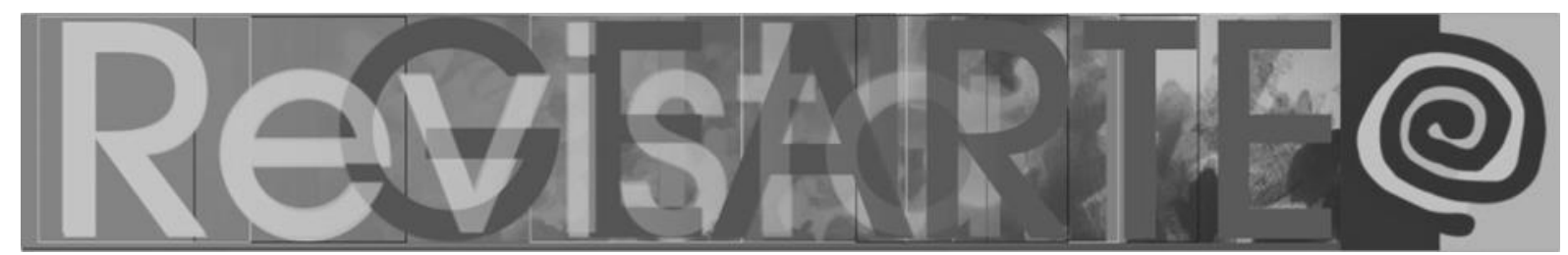

Figura 23 - Giuseppe Campuzano, Línea de vida/Museo Travesti del Peru. Fotografia de Leo Eloy, Fundação Bienal de São Paulo

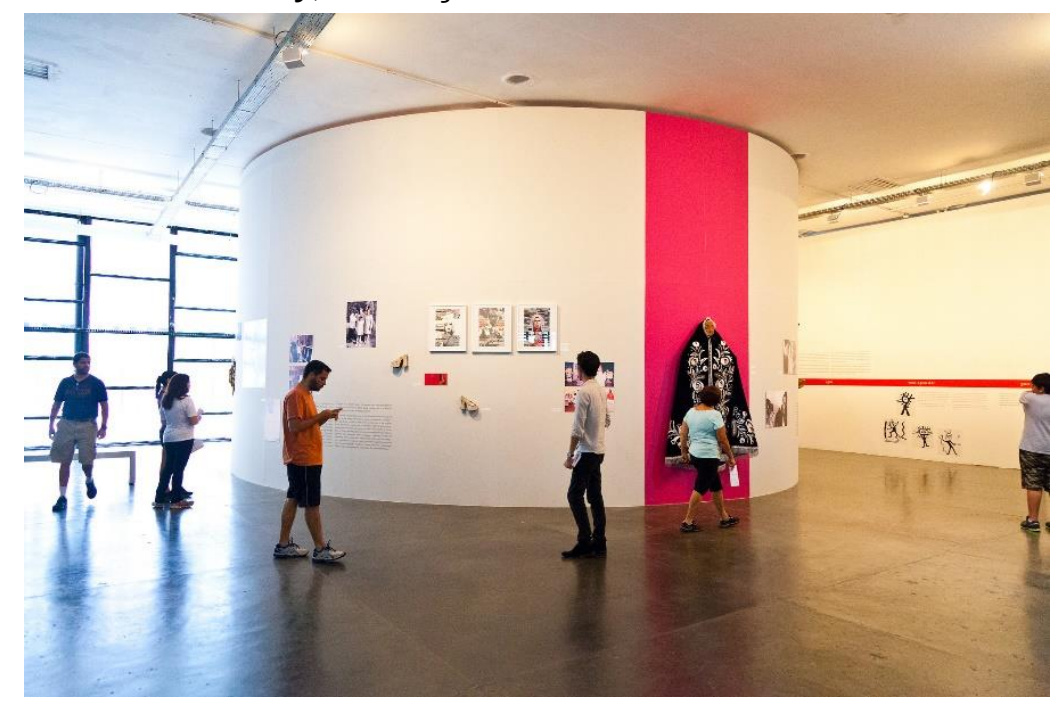

Fonte: Fundação Bienal de São Paulo. ${ }^{50}$

Figura 24 - Sergio Zevallos, Nahum Zenil, Pedro Lemebel, Francisco Casas, Ocaña, Dios es marica. 31ㄹ Bienal de São Paulo, 2014

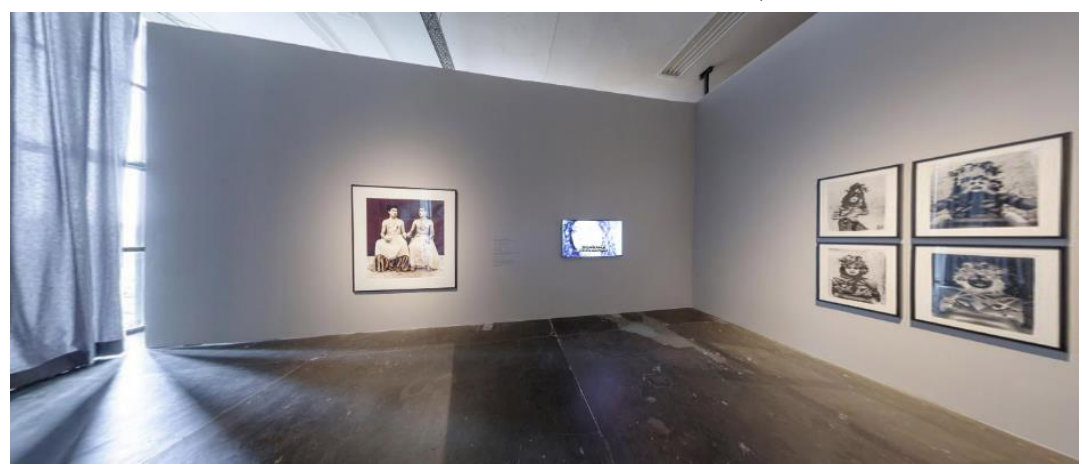

Fonte: Fundação Bienal de São Paulo. ${ }^{51}$

A produção artística contemporânea vem somar à luta incansável d@s que estão diretamente empenhad@s em reconceitualizar a visão pejorativa e depreciativa sobre a população LGBT e, principalmente, gay. Sendo assim, as Artes Visuais assumem papel relevante quando seus criadores se propõem a tratar de temas tão delicados e as lançam aos olhos de uma sociedade conservadora. "(...) as representações também podem ser consideradas o meio pelos quais os indivíduos, grupos e instituições

50 Disponível em: <http://saopaulobienalstories.org/gallery.php.>. Acesso em: 20 nov. 2018.

51 Disponível em: <http://www.bienal.org.br/publicacoes>. Acesso em: 20 nov. 2018. 


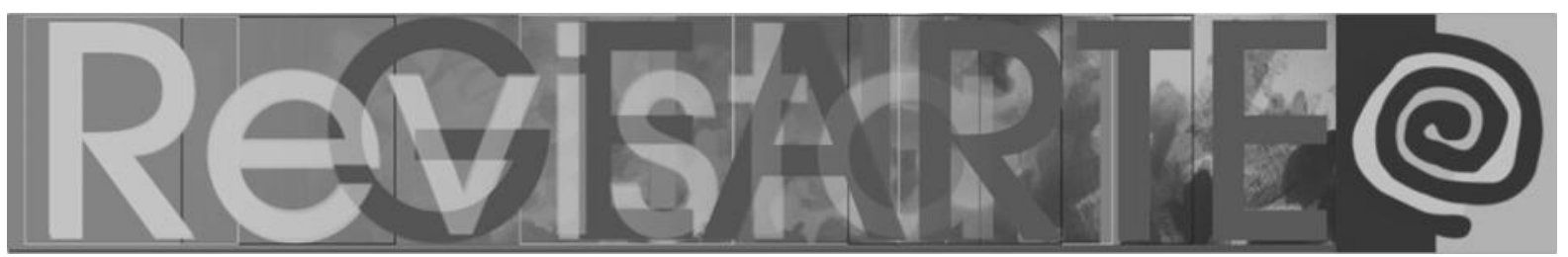

manifestam suas ideias e suas percepções de mundo, sua imaginação a fim de estabelecer uma relação de comunicação (...)" (SILVA, 2008, p. 3).

Ao longo da história da arte muitos trabalhos foram elaborados por artistas que se dispuseram a retratar, entre tantos motivos, a vida íntima, a sexualidade (homossexualidades) e gêneros através dos meios expressivos mais tradicionais até os recursos atuais mais avançados tecnologicamente. No entanto, nem todas essas imagens têm ou tiveram uma ampla veiculação.

Há, de fato, imagens que registram a existência e práticas homoeróticas, em diversos períodos da história da arte. Porém, ainda são pouco divulgadas e, em alguns casos, censuradas como o trabalho da artista brasileira Márcia $X^{52}$ e do artista estadunidense Mapplethorpe. ${ }^{53}$ Elas dificilmente chegam até nós, mesmo nos lugares onde deveriam estar, como por exemplo: nos livros didáticos ou nas aulas de arte. Não é à toa que pouco nos chegam informações ou registros imagéticos, de trabalhos que abordem como temática as homossexualidades. A não ser alguns produzidos nas últimas décadas e expostos em razão das mudanças e transformações em alguns países como Portugal, Espanha, França, Alemanha, Bélgica, Estados Unidos entre outros.

No movimento artístico denominado Queer $A r t^{54}$ encontramos a arte erótica (com ênfases no homoerotismo), a arte conceitual e a arte contextual (com ênfases nas pautas do movimento LGBT). A arte contemporânea tem o propósito de causar dúvidas, provocar, inquietar e desestabilizar a estrutura enrijecida e imposta culturalmente. "(...) já não busca mais o novo, nem o espanto, como as vanguardas da primeira metade deste século, mas sim querem propor o estranhamento ou o

52 Ver: <http://adeildoleite.blogspot.com.br/>. Acesso em: 21 nov. 2018.

53 Ver: <http://www.mocp.org/detail.php?type=related\&kv=6956\&t=objects>. Acesso em: 21 nov. 2018.

54 A Queer Art é identificada como um movimento artístico não reconhecido oficialmente, que se potencializou a partir da década de 1980 no continente europeu e nos Estados Unidos. Traz em suas representações questões de cunho homossexual relacionado à arte conceitual, contextual e erótica. 


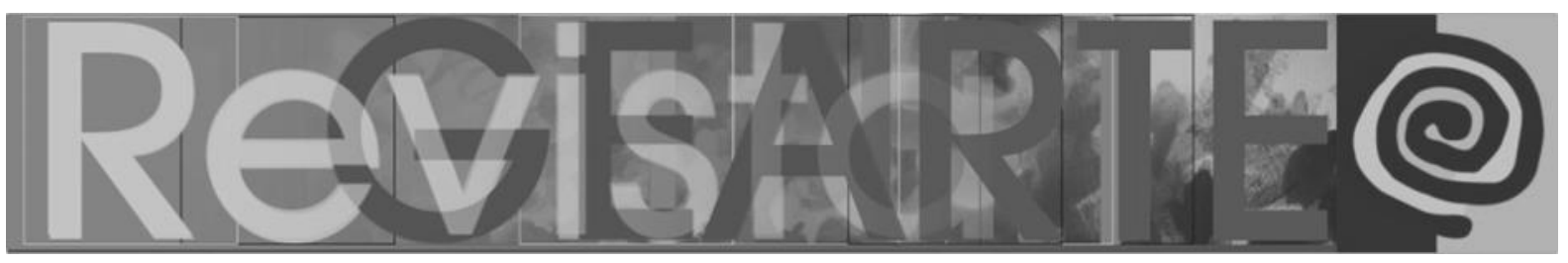

questionamento da linguagem da qual se utiliza e de que forma sua leitura é feita ou compreendida" (EFLAND; FREEDMAN; STUHR, 2003, p. 53)

A arte contemporânea permite uma abertura de criações que agregam pluralismo cultural. Transitar por territórios variados, abstração extrema, incorporação e mescla de elementos do presente e do passado, bem como o trabalho coletivo ou em duplas de artistas, ${ }^{55} 56$ são algumas das características dessa arte. "Pares e grupos de artistas, como Gilbert Proesch (1943) \& George Passmore (1942), trabalham juntos para desafiar o mito heroico do gênio individual, dando ênfase, às vezes, nos defeitos mais correntes." (EFLAND, FREEDMAN, STUHR, 2003, p. 67)

Recentemente assistimos ao cancelamento da exposição Queermuseu Cartografias da diferença na arte brasileira, promovida pelo Santander Cultural de Porto Alegre. O principal motivo do cancelamento teria sido em razão de a exposição promover a "pedofilia, a zoofilia e o desrespeito às religiões", conforme publicado pelo jornal O Globo em março de 2018. No entanto, essa não foi a primeira vez em que uma exposição foi atacada por uma onda de conservadorismo que tem tomado nosso país. Em 2006, tivemos a censura à obra Desenhando com Terços de Márcia X, que fazia parte da exposição Erótica e exibida no Centro Cultural do Banco do Brasil CCBB/ Rio de Janeiro. Logo após o ocorrido, o Ministro da Cultura, Gilberto Gil, torna público nota que reproduzimos:

Brasília, 25 de abril de 2006.

Toda censura é inaceitável. Os critérios para seleção de obras exibidas numa instalação devem ser de natureza estética, sob a responsabilidade de curadores ou de quem for designado para a tarefa.

Dessa forma, o Ministério da Cultura estranha a censura feita à obra de Márcia X, na instalação Erótica, no Centro Cultural Banco do Brasil (CCBB) do Rio de Janeiro.

Acreditamos na capacidade de discernimento crítico dos espectadores e do público em geral. Assim como acreditamos que toda tutela na relação entre obra de arte e espectador é inaceitável.

55 Ver: <https://www.tate.org.uk/whats-on/tate-modern/exhibition/gilbert-george>. Acesso em: 21 nov. 2018.

56 Ver: <https://news.sky.com/story/gilbert-george-prepare-to-open-new-exhibition-at-the-white-cubebermondsey-11137380 >. Acesso em: 21 nov. 2018. 


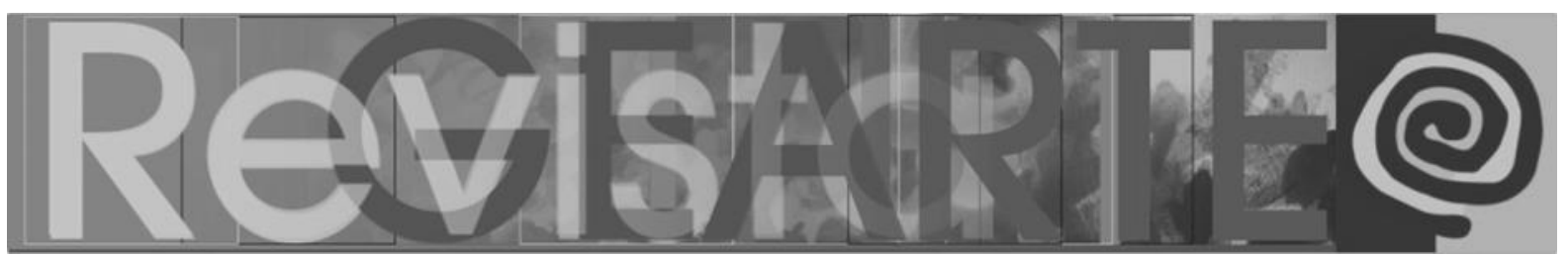

Segundo a Constituição Brasileira, é "livre a expressão da atividade intelectual, artística, científica e de comunicação, independentemente de censura ou licença". Por isso, não pode haver mais em nosso país nenhum tipo de interdição a obras de arte e a outras formas de expressão.

Esperamos que a decisão do CCBB seja revista em nome da liberdade garantida por lei.

Gilberto Gil (Ministro de Estado da Cultura) ${ }^{57}$

Artistas, curadores, museus, centros culturais e galerias estão enfrentando situações semelhantes em diversos outros lugares do Brasil e do mundo e esta onda neoconservadora tem serias implicações para a produção artística, mas também para o ensino de artes visuais uma vez que todo o sistema da arte tem sido alvo de policiamento e criminalização quando o objeto de exibição e apreciação é interpretado sob o viés de olhares que se educaram ou são educados para negar a diversidade cultural e humana ao longo da história e da história atual. Nesse sentido, ainda vivemos sob o manto do projeto imperial/colonial.

Em 2010 nos Estados Unidos a Liga Católica pressionou a National Portrait Gallery a retirar de uma exposição em cartaz sobre sexualidade o vídeo $\underline{A \text { Fire in } M y}$ Belly (trecho) do artista David Wojnarowicz (1954-1992). A obra de 1987 tem duração de 30 minutos e ao longo de 11 segundos apresenta formigas caminhando sobre uma imagem de Jesus Cristo na cruz. ${ }^{58}$

O trecho do vídeo situado em seu contexto de produção nos coloca diante das questões referentes ao HIV/AIDS que, nos anos de 1980, passou a ser um problema enfrentado mundialmente e que ainda nos afeta, pese os avanços obtidos nas últimas décadas. Wojnarowcz não foi o único artista a tratar do tema em sua obra e como ele muitos procuraram abordar o sofrimento das pessoas vitimadas pela doença, assim como, pela perda de seus parceiros. O vídeo, portanto, é uma homenagem a seu parceiro que faleceu de AIDS e, também, às demais vítimas da epidemia no mundo.

57 Publicado na página de Márcia $X$ em abril de 2006: <http://marciax.art.br/mxText.asp?sMenu=4\&sText=47>. Acesso em: 21 nov. 2018.

58 Ver: <http://adobeairstream.com/art/david-wojnarowicz-a-fire-in-my-belly-pulled-fromsmithsonian/>. Acesso em: 21 nov. 2018. 


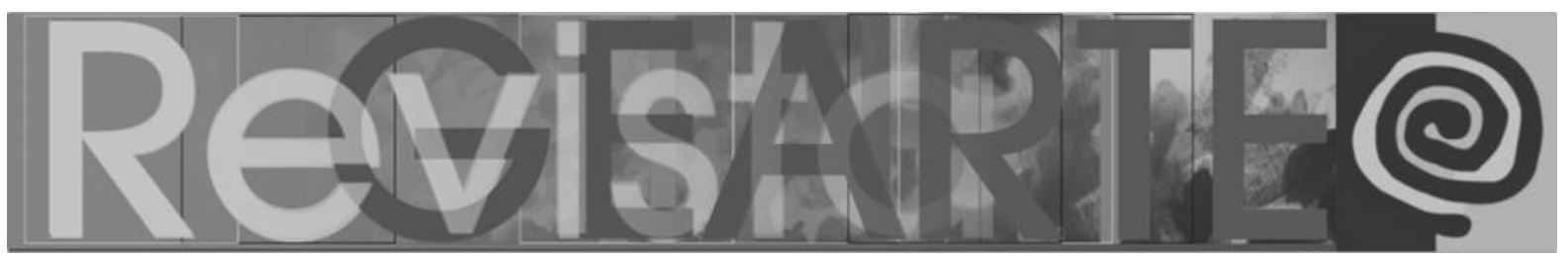

Paralelamente à produção artística e seu discurso poético/político, o governo brasileiro criou em 2004, no primeiro mandato do então Presidente Luiz Inácio Lula da Silva, o Programa Brasil Sem Homofobia, na perspectiva de promover a cidadania e os direitos humanos de Lésbicas, Gays, Bissexuais, Travestis e Transexuais - LGBT, a partir da equiparação de direitos e do combate à violência, à discriminação e à LGBTfobia. Coube à Secretaria de Direitos Humanos da Presidência da República (SDH/PR) coordenar as diversas ações tais como: ações de capacitação e desenvolvimento, apoio a projetos de governos estaduais, municipais e organizações não governamentais e implantação de centros de referência para combate à homofobia em todo o país ${ }^{59}$.

Dentro do Programa Brasil Sem Homofobia, foi criado e financiado, entre outras políticas, o Projeto Escola Sem Homofobia iniciado em 2008, com o propósito de tentar combater a homofobia dentro do ambiente escolar. O Projeto contou com a participação de entidades como: a ONG Pathfinder do Brasil, Gale - Aliança pela Educação LGBT, a Reprolatina (Soluções Inovadoras em Saúde Sexual e Reprodutiva), a Ecos (Comunicação em Sexualidade) e a Associação Brasileira de Lésbicas, Gays, Bissexuais, Travestis e Transexuais - ABGLT.

O material proposto pelo Projeto Escola Sem Homofobia é composto por um kit contendo: o caderno do educador, seis boletins para os estudantes e cinco vídeos. Direcionado somente para o Ensino Médio, aborda conteúdos referentes à sexualidade, diversidade sexual, homofobia e ainda traz orientações de como lidar com a população LGBT.

Infelizmente o Projeto Escola Sem Homofobia foi severamente atacado por forças conservadoras no Congresso Nacional e na Câmera dos Deputados, além de outros segmentos da sociedade brasileira vinculados a religiões e partidos políticos, o que ocasionou na suspensão de parte do projeto. O kit deveria ser adotado pelas

59 Secretaria de Direitos Humanos: <https://www.jusbrasil.com.br/topicos/28177414/secretaria-dedireitos-humanos-da-presidencia-da-republica-sdh-pr> Acesso em: 22 nov. 2018. 


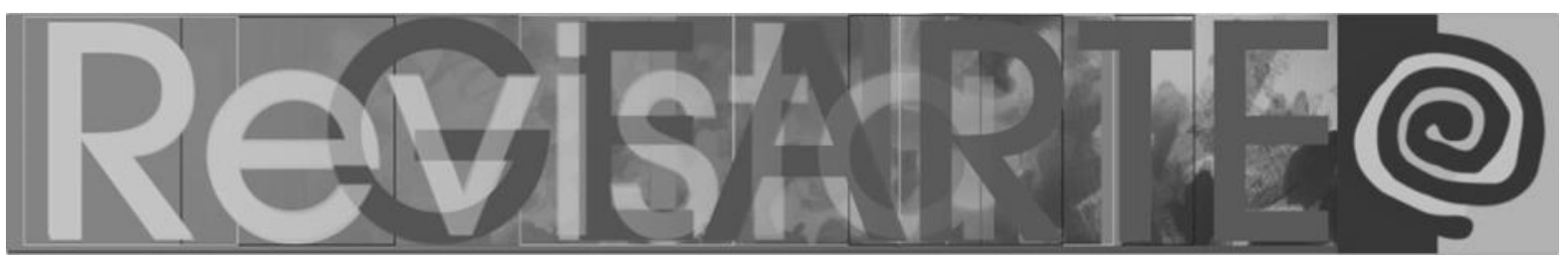

escolas, pois se constitui numa ferramenta de apoio àquele/as professore/as que não sabem como proceder e abordar as questões de sexualidade de maneira mais ampla com seus estudantes, porém teve sua produção e distribuição suspensa até o momento.

$(\mathrm{Re})$ existir significa combater o fascismo e seu projeto de criminalização das homossexualidades, porém nosso horizonte emancipatório é que a LGBTfobia seja eliminada de nossas culturas. Para que tal utopia seja alcançada é necessário deslocar nossa compreensão para o que nos alerta Bimbi (2017):

Tratá-los como doentes é justificá-los: "Coitadinhos, estão mal da cabeça". E é errar na busca de soluções: se entendermos a homofobia como um fenômeno sócio político e não psiquiátrico, vamos perceber que a resposta é educar a partir da escola, dos meios de comunicações, da arte, das políticas públicas e de outras ferramentas úteis contra o preconceito, divulgar informações veraz sobre sexualidade, garantir a igualdade de direitos e a afirmação da dignidade das minorias, e combater com a política e a lei aqueles que, geralmente por interesse e não por convicção, promovem o ódio contra os gays. É isto, e não um ansiolítico, um antipsicótico ou um divã, que vai acabar com a homofobia nas próximas gerações." (BIMBI, 2017, p. 143)

Lidar com a LGBTfobia como um fenômeno sociopolítico e cultural mudaria completamente os rumos da história de nossa humanidade. Como nos diz Steve Walker (1961-2012), pintor canadense (2010) ${ }^{60}$

Como homossexual fui movido, educado e inspirado por trabalhos que lidam com um contexto heterossexual. Por que eu suporia que um heterossexual seria incapaz de apreciar o trabalho que fala sobre temas comuns na vida, como visto através dos meus olhos como um homem gay? Se a população heterossexual é incapaz de fazer isso, então a perda é deles, não minha. (s.n.t.)

Do conjunto de pinturas do Walker, destaco algumas imagens ${ }^{61} 62$ que expressam o que esperamos para o nosso presente enquanto população LGBT e

60 Ver: <https://www.gingerbreadsquaregallery.com/Paintings/Walker/Walker-Bio/walker-bio.html>. Acesso em: 21 nov. 2018.

61 Ver: <https://nolanlewismrgayindia2013.wordpress.com/2013/05/06/the-art-of-steve-walker/>. Acesso em: 21 nov. 2018.

62 Ver: <http://artodyssey1.blogspot.com/2013/04/steve-walker-1961-2012.html>. Acesso em: 22 nov. 2018.

COSTA, Fábio José Rodrigues da. Ensino/Aprendizagem das Artes Visuais na 


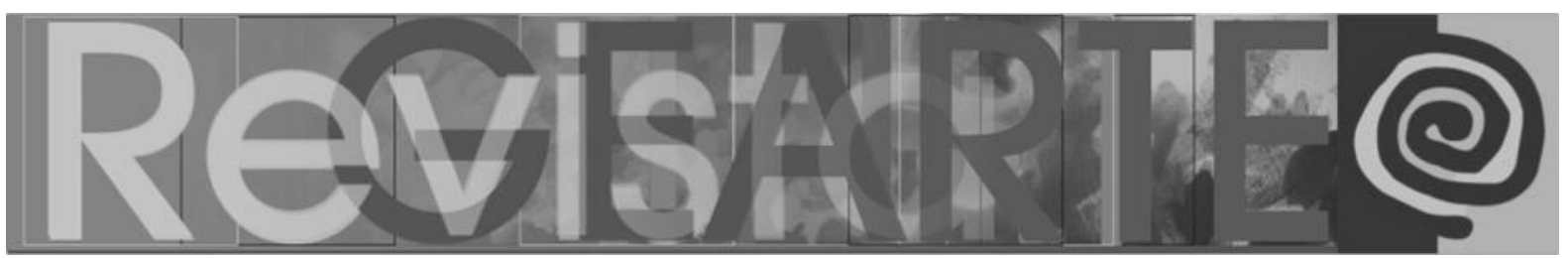

acredito de verdade que o acesso a produção artística de ativista/artivistas Igbt colaborem para que aprendamos a desaprender sobre nós mesmos e provoque uma mudança de imaginário sobre a população LGBT, mas acredito também que para isso seja necessário continuarmos desobedientes epistemologicamente.

\title{
Uma síntese da mais desejada utopia pedagógica do século XXI foi expressada
} por Bimbi (2017) e é também um gesto de (re)existência e desobediência epistêmica.

\begin{abstract}
O que pode acontecer, se a escola e a família educarem para a aceitação da diversidade e contra o preconceito, é que esse menino gay - sabendo ou não que é gay - não vai sofrer. Poderá viver sua infância, sua adolescência e sua juventude como qualquer outro e chegar à idade adulta sem os traumas causados pela violência e os preconceitos de outros. $E$, do mesmo modo, esse menino hétero não vai praticar bullying contra seu colega gay na escola e, ao crescer, não se transformará em um adulto preconceituoso e cheio de ódio, medo ou repulsa contra os que não são como ele, contra aqueles que simplesmente amam diferente. (BIMBI, 2017, p. 106)
\end{abstract}

\section{Referências}

ALIAGA, Juan Vicente; CORTÉS, José Miguel G. Desobediencias: Cuerpos disidentes y espacios subvertidos en el arte en América Latina y España: 1960-2010. Barcelona; Madrid: EGALES, 2014.

BAZÁN, Osvaldo. Historia de la homosexualidad en la Argentina. Buenos Aires: Marea, 2010.

BIMBI, Bruno. O fim do armário: lésbicas, gays, bissexuais e trans no século XXI. Rio de Janeiro: Garamond, 2017.

BORRILLO, Daniel. Homofobia: história e crítica de um preconceito. Belo Horizonte: Autêntica, 2010.

CASTRO-GÓMEZ, Santiago. La Poscolonialidade explicada a los niños. Popayán/Colombia: Editorial Universidad del Cauca; Instituto Pensar, Universidad Javeriana, 2005.

CORTÉS, José Miguel G. El cuerpo de la ciudad: mapas del deseo. In: ALIAGA, Juan Vicente; CORTÉS, José Miguel G. Desobediencias: Cuerpos disidentes y espacios subvertidos en el arte en América Latina y España: 1960-2010. Barcelona; Madrid: EGALES, 2014.

DUARTE, Gustavo de Oliveira; BERTÉ, Odailso Sinvaldo. Entre barba e purpurina: pedagogias e dramaturgias ao estilo Dzi Croquettes. Urdimento, v. 2, n. 32, p. 488-504, Set. 2018.

EFLAND, Arthur; FREEDMAN, Kerry; STUHR, Patricia. La educación en el arte posmoderno. Barcelona: Paidós, 2003.

FREIRE, Deolinda de Jesus. Theodor de Bry e a narrativa visual da Brevísima Relación de la Destruición de las Indias. Revista USP, São Paulo, n. 77, p. 200-215, mar./maio 2008.

FREIRE, Paulo. Pedagogia da indignação: cartas pedagógicas e outros escritos. São Paulo: Editora UNESP, 2000.

FRY, Peter; MACRAE, Edward. O que é homossexualidade. 3. ed. Coleção Primeiros Passos. São Paulo: Brasiliense, 1984. 


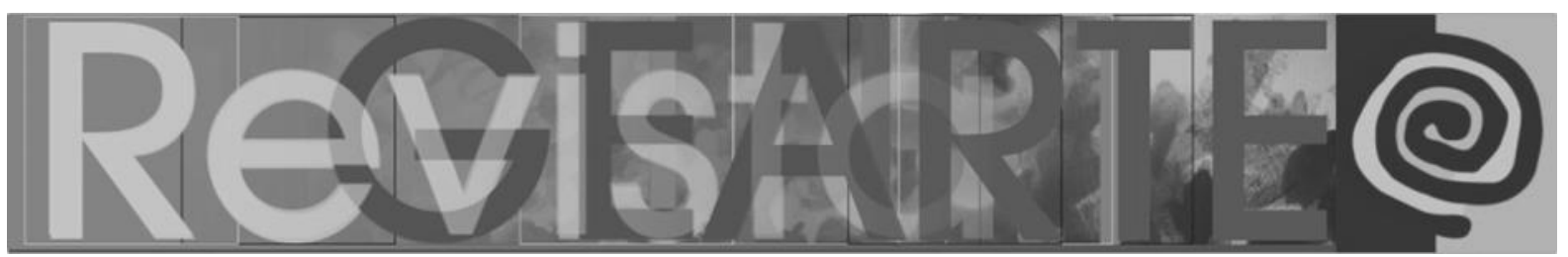

GATTI, José. Mais amor e mais tesão: história da homossexualidade no Brasil. Entrevista concedida a José Gatti por James Green. São Paulo. Unesp, 2000.

GRUZINSKI, Serge. A Guerra das imagens: de Cristóvão Colombo a Blade Runner (1492-2019). São Paulo: Companhia das Letras, 2006.

LORD, Catherine; MEYER, Richard. Art and Queer Culture. New York, NY: Phaidon, 2013.

LOURO, Guacira Lopes (Org.). O corpo educado: pedagogias da sexualidade. Belo Horizonte: Autêntica, 2018.

LOURO, Guacira Lopes. Teoria Queer: uma política pós-identitária para a educação. Revista Estudos Feministas, Florianópolis, UFSC, v. 9, n. 2, p. 541- 553, 2001.

MARQUES FILHO, Adair. Arte e cotidiano: experiência homossexual, teoria queer e educação. 2007. 125 f. Dissertação (Mestrado em Processos e Sistemas Visuais, Educação e Visualidade) Universidade Federal de Goiás, Goiânia, 2007.

MIGNOLO, Walter D. Desobediência epistêmica: a opção descolonial e o significado de identidade em política. Cadernos de Letras da UFF - Dossiê: Literatura, língua e identidade, n, 34, p. 287-324, 2008.

MOTT, Luiz. Homo-Afetividade e Direitos Humanos. Revista Estudos Feministas, Florianópolis, v. 14, n. 2, p. 509-521, maio/ago. 2006.

MOTT, Luiz. A revolução homossexual: o poder de um mito. Revista USP, São Paulo, n. 49, p. 40-59, mar./maio 2001.

MOTT, Luiz. Os filhos da dissidência: o pecado da sodomia e sua nefanda matéria. Revista Tempo, Universidade Federal Fluminense, v. 6, n. 11, p. 189-20, jul. 2001.

OKITA, Hiro. Homossexualidade da opressão à libertação. São Paulo: Sundermann, 2007.

PINHO, Fabio Assis. Aspectos éticos em representação do conhecimento em temáticas relativas à homossexualidade masculina: uma análise da precisão em linguagens de indexação brasileiras. 2010. Tese (Doutorado em Ciência da Informação) - Universidade Estadual Paulista, Faculdade de Filosofia e Ciências, 2010. Marília/São Paulo, 2010.

PRADO, Marco Aurélio Máximo. Homofobia: muitos fenômenos sob o mesmo nome. In: BORRILLO, Daniel. Homofobia: história e crítica de um preconceito. Belo Horizonte: Autêntica, 2010.

RESENDE, Ricardo. Posição amorosa: Hudinilson Jr. São Paulo: WMF Martins Fontes, 2016.

SANTOS, Giovanna Aparecida Schittini dos. Relações de gênero no livro $V$ das Ordenações Manuelinas (Portugal - Século XVI). Simpósio Nacional de História - ANPUH. 26. Anais... São Paulo, julho 2011.

SCHWAB, Jean-Luc; BRAZDA. Rudolf. Triângulo rosa: um homossexual no campo de concentração nazista. São Paulo: Mescla, 2011.

SIMÕES, Júlio Assis. Do movimento homossexual ao LGBT. São Paulo: Editora Fundação Perseu Abramo, 2009.

SILVA, Fábio Ronaldo. A representação de homossexuais nas revistas DOM e Júnior. Campina Grande: UFCG, 2008.

TREVISAN, João Silvério. Devassos no paraíso: a homossexualidade no Brasil da colônia à atualidade. Rio de Janeiro: Objetiva, 2018. 


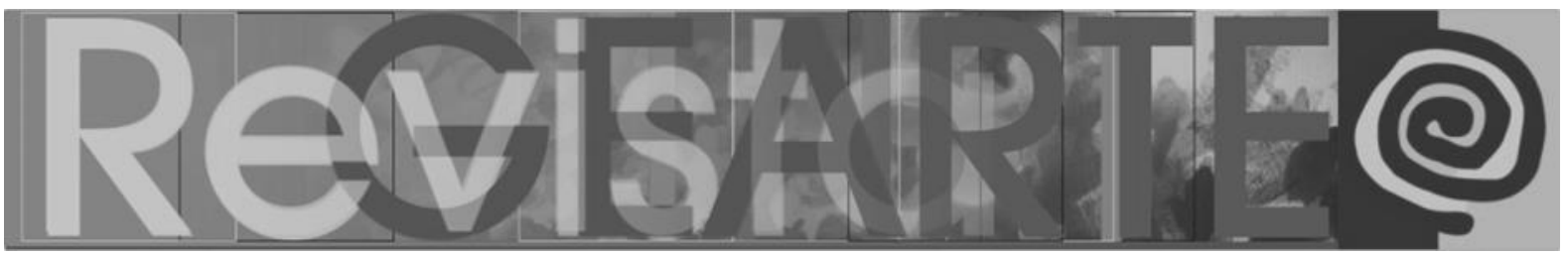

\section{Fábio José Rodrigues da Costa}

Doutor em Artes pelo Escola de Belas Artes da Universidade Federal de Minas Gerais - UFMG e Doutor em Artes Visuais pela Universidad de Sevilla - Espanha. Realizou estágio de Pós-doutorado em Artes pela Escola de Belas Artes da Universidade Federal de Minas Gerais - UFMG. Professor Associado do Departamento de Artes Visuais do Centro de Artes da Universidade Regional do Cariri - URCA e líder do Grupo de Pesquisa Ensino da Arte em Contextos Contemporâneos - GPEACC/CNPq.

Email: fabio.rodrigues@urca.br

Currículo: http://lattes.cnpq.br/8911805265683899

Recebido em 20 de março de 2019

Aceito em 21 de maio de 2019 